\title{
Engraftment in Nonobese Diabetic Severe Combined Immunodeficient Mice of Human CD34+ Cord Blood Cells After Ex Vivo Expansion: Evidence for the Amplification and Self-Renewal of Repopulating Stem Cells
}

\author{
By Wanda Piacibello, Fiorella Sanavio, Antonella Severino, Alessandra Danè, Loretta Gammaitoni, \\ Franca Fagioli, Eliana Perissinotto, Giuliana Cavalloni, Orit Kollet, Tsvee Lapidot, and Massimo Aglietta
}

\begin{abstract}
Understanding the repopulating characteristics of human hematopoietic stem/ progenitor cells is crucial for predicting their performance after transplant into patients receiving high-dose radiochemotherapy. We have previously reported that $\mathrm{CD}_{34}{ }^{+}$cord blood (CB) cells can be expanded in vitro for several months in serum containing culture conditions. The use of combinations of recombinant early acting growth factors and the absence of stroma was essential in determining this phenomenon. However, the effect of these manipulations on in vivo repopulating hematopoietic cells is not known. Recently, a new approach has been developed to establish an in vivo model for human primitive hematopoietic precursors by transplanting human hematopoietic cells into sublethally irradiated nonobese diabetic severe combined immunodeficient (NOD/SCID) mice. We have examined here the expansion of cells, $\mathrm{CD}_{34}^{+}$and $\mathrm{CD}^{+} 4^{+} 38^{-}$ subpopulations, colony-forming cells (CFC), long-term culture initiating cells (LTC-IC) and the maintenance or the expansion of SCID-repopulating cells (SRC) during stromafree suspension cultures of human $\mathrm{CD} 4^{+} \mathrm{CB}$ cells for up to 12 weeks. Groups of sublethally irradiated NOD/SCID mice were injected with either 35,000, 20,000, and 10,000 unmanipulated CD34+ ${ }^{+}$B cells, which were cryopreserved at the start of cultures, or the cryopreserved cells expanded from
\end{abstract}

A N ESSENTIAL PROPERTY of hematopoietic stem cells is their ability to divide without significant alteration of their proliferative potential or differentiation state. Characterization and quantitation of these progenitor cells is fundamental to our understanding of the developmental sequence, and it is of great importance for human hematopoietic cell transplantation, ex vivo expansion, and gene therapy. ${ }^{1-4}$ To date, quantitative analysis of human primitive hematopoietic cells has been

From the Department of Biomedical Sciences and Human Oncology, University of Torino Medical School, Torino; the Hematology/Oncology Section, Mauriziano Hospital, Torino; the Pediatric Department; the Institute for Cancer Research and Treatment (IRCC), Candiolo, Torino, Italy; and the Department of Immunology, the Weizmann Institute of Science, Rehovot, Israel.

Submitted May 11, 1998; accepted January 29, 1999.

Supported by grants from Associazione Italiana per la Ricerca sul Cancro (AIRC; Milan, Italy) and from the Ministero dell'Università e della Ricerca Scientifica e Tecnologica (MURST) (to W.P. and M.A.). A.D. is a recipient of the FIRC grant; A.S. and L.G. are both recipients of the "G. Ghirotti Foundation," sez. Piemonte grants.

Address reprint requests to Wanda Piacibello, MD, Department of Biomedical Sciences and Human Oncology, Clinical Section, Via Genova 3, 10126 Torino, Italy; e-mail: w.piacibello@mail.ircc.unito.it.

The publication costs of this article were defrayed in part by page charge payment. This article must therefore be hereby marked "advertisement" in accordance with 18 U.S.C. section 1734 solely to indicate this fact.

(c) 1999 by The American Society of Hematology.

0006-4971/99/9311-0001\$3.00/0
$35,000,20,000$, or 10,000 CD $34^{+}$cells for 4,8 , and 12 weeks in the presence of a combination of early acting recombinant growth factors (fit 3/flk2 ligand [FL] + megakaryocyte growth and development factor [MGDF] \pm stem cell factor [SCF] \pm interleukin-6 [IL-6]). Mice that had been injected with $\geq 20,000$ fresh or cryopreserved uncultured CD34+ cells did not show any sign or showed little engraftment in a limited number of animals. Conversely, cells that had been generated by the same number of initial CD34 ${ }^{+}$CB cells in 4 to 10 weeks of expansion cultures engrafted the vast majority of NOD/SCID mice. The level of engraftment, well above that usually observed when the same numbers of uncultured cells were injected in the same recipients (even in the presence of irradiated CD34- cells) suggested that primitive hematopoietic cells were maintained for up to 10 weeks of cultures. In addition, dilution experiments suggest that SRC are expanded more than 70-fold after 9 to 10 weeks of expansion. These results support and extend our previous findings that CD34+ CB stem cells (identified as LTC-IC) could indeed be grown and expanded in vitro for an extremely long period of time. Such information may be essential to design efficient stem cell expansion procedures for clinical use.

(c) 1999 by The American Society of Hematology.

limited to in vitro studies using colony assays (colony-forming cells [CFC]) or long-term cultures (LTC). CFC assays detect only committed and multipotent progenitors. LTC assays detect more primitive cells (LTC-initiating cells [IC]), capable of generating myeloid colonies for at least 5 weeks of culture on competent feeder layers. 5,6

The transplantation assay available in the mouse system has been instrumental in defining and characterizing the most primitive elements of the hematopoietic system. ${ }^{7}$ Recently, a similar in vivo approach, derived from the work in the mouse, has become available for humans. As a result, several groups have transplanted human hematopoietic precursors into different mouse mutants in an attempt to develop a reproducible transplantation assay. ${ }^{7-9}$ In particular, the intravenous injection of human hematopoietic precursors in sublethally irradiated severe combined immunodeficient (SCID) and nonobese diabetic/SCID (NOD/SCID) mice has resulted in the engraftment of primitive human cells that proliferate and differentiate to multiple lineages in the murine bone marrow (BM) and spleen. ${ }^{10-13}$ The transplanted human cells home to and engraft the murine $\mathrm{BM}$, where they proliferate and differentiate to produce large numbers of LTC-IC, CFC, immature and mature myeloid, erythroid, and lymphoid cells without the influence of exogenously supplied human growth factors. ${ }^{14}$ The engrafted human cells have been defined SCID-repopulating cells (SRC) ${ }^{15}$ or, in a similar quantitative assay, competitive repopulating units (CRU). ${ }^{16}$ Although the SRC (or CRU) represents a very primitive hematopoietic cell, the exact place in the stem cell 
hierarchy and its relation to early in vitro hematopoietic progenitors, such as LTC-IC, is not fully understood. SRC have been reported to be biologically distinct from and more primitive than most CFC and LTC-IC: SRC are exclusively $\mathrm{CD} 34^{+} \mathrm{CD} 38^{-}$in contrast to CFC and LTC-IC, which are found also in the $\mathrm{CD} 34^{+} \mathrm{CD} 38^{+}$fraction. ${ }^{17-19}$ By contrast, according to Eaves's data, even though the cells identified by the LTC-IC and the CRU assay may not necessarily represent identical cell populations, they belong to both $\mathrm{CD} 34^{+} \mathrm{CD} 38^{+}$and $\mathrm{CD} 34^{+} \mathrm{CD} 38^{-}$subpopulations and seem to increase in response to the same culture conditions in vitro. ${ }^{16}$

We conclude that this experimental transplantation assay that measures the repopulating potential of various human progenitor fractions is most valuable in increasing our understanding of several biological properties of hematopoietic progenitors for both experimental and clinical hematology.

A second very important issue, to date, is the identification of culture conditions that support the self-renewal and the expansion of human hematopoietic stem cells. In particular, cord blood (CB) has recently attracted attention as a source of hematopoietic stem cells for both transplantation and gene therapy applications. ${ }^{20-24}$ However, concern that a single CB collection may not be sufficient to guarantee engraftment of adult allogeneic recipients has also stimulated considerable interest in expanding CB stem cell number in vitro. Experiments conducted in our laboratories as well as data from others have recently shown that $\mathrm{CD} 34^{+}$(or $\mathrm{CD} 34^{+} \mathrm{CD} 38^{-}$) $\mathrm{CB}$ cells can indeed be expanded in fairly well-defined culture conditions. ${ }^{25-29}$ The common denominator of the expansion systems was the absence of stroma layers and hence the use of combinations of recombinant early acting hematopoietic growth factors. A net expansion of LTC-IC was observed in all cases. $^{25-29}$ In addition, it was shown that 4-day or 5- to 8-day stroma-free liquid cultures of $\mathrm{CB}$ cells in the presence of flt3/flk2 ligand (FL), stem cell factor (SCF), interleukin-3 (IL-3), IL-6 without ${ }^{29}$ or with granulocyte colony-stimulating factor (G-CSF) ${ }^{16}$ supported LTC-IC expansion and also a modest, albeit significant expansion, of CRU in NOD/SCID mouse recipients. Conversely, it has been reported that cocultures of human BM and CB cells with allogeneic human stroma resulted in a reduced repopulating capacity of cocultured cells, which, by contrast, contained an equal or even higher number of CFC and LTC-IC as compared with uncultured cells. ${ }^{30}$ On the other hand, very recently $\mathrm{Xu}$ et $\mathrm{al}^{31}$ reported that in vivo long-term repopulating hematopoietic stem cells from CB could be maintained for at least 4 weeks when cocultured on a stroma cell line derived from the aorta-gonad-mesonephros region of mouse embryo.

The aim of our studies was to investigate whether the combinations of early acting growth factors, which in our previous studies proved capable of inducing a massive and prolonged expansion of hematopoietic progenitors and more primitive LTC-IC from CB cells, ${ }^{27,28}$ could also maintain the in vivo repopulating ability of human stem cells, or even amplify their number.

We show that $\mathrm{CD} 34^{+} \mathrm{CB}$ cells can be expanded for up to 10 weeks in stroma-free cultures in the presence of FL, megakaryocyte growth and development factor (MGDF), SCF, and IL-6 without losing their in vivo repopulating potential. Furthermore, our studies show that considerable expansion of SRC is obtainable in vitro, as sublethally irradiated NOD/ SCID mice are consistently and reproducibly repopulated by the equivalent of $1,250,625$, and 312 initial CD34 ${ }^{+} \mathrm{CB}$ cells, which have been expanded in vitro for up to 9 to 10 weeks.

\section{MATERIALS AND METHODS}

Human cells. Human BM was obtained by aspiration from the posterior iliac crest of fully informed hematologically normal donors. Umbilical CB was obtained at the end of full-term deliveries, after clamping and cutting of the cord, by drainage of blood into sterile collection tubes containing the anticoagulant citrate-phosphate dextrose.

$\mathrm{CD} 4^{+}$cell purification. Mononuclear cells (MNC) were isolated from CB using Ficoll Hypaque (density, 1077; Nyegaard, Oslo, Norway) density centrifugation. Cells were subjected to two cycles of plastic adherence (60 minutes each); they were then washed with Hanks' Balanced Salt Solution (HBSS, GIBCO BRL, Grand Island, $\mathrm{NY}$ ). The $\mathrm{CD}_{3}{ }^{+} \mathrm{MNC}$ fraction was isolated with superparamagnetic microbead selection using high-gradient magnetic field and miniMACS column (Miltenyi Biotech, Gladbach, Germany). The efficiency of the purification was verified by flow cytometry counterstaining with a CD34-phycoerythrin (PE; HPCA-2; Becton Dickinson, San Jose, CA) antibody. In the cell fraction containing purified cells, the percentage of $\mathrm{CD} 4^{+}$cells ranged from $90 \%$ to $98 \%$.

Recombinant human cytokines. The following recombinant purified human cytokines were used in these studies: recombinant human (rh) stem cell factor (rhSCF) and rh megakaryocyte growth and development factor (MGDF) were a generous gift from Amgen (Thousand Oaks, CA); recombinant human granulocyte colonystimulating factor (rhG-CSF) was from Genzyme (Cambridge, MA); recombinant human granulocyte-macrophage colony-stimulating factor (rhGM-CSF), recombinant human interleukin-6 (rhIL-6) and recombinant human interleukin-3 (rhIL-3) were from Sandoz (Basel, Switzerland); recombinant human erythropoietin (rhEPO; EPREX) was from Cilag (Milan, Italy); recombinant human FLT3-ligand (rhFL) was kindly provided by S.D. Lyman (Immunex Corp, Seattle, WA).

Animals. NOD/LtSz scid/scid (NOD/SCID) mice were obtained from Charles River Italia (Calco, Italy) and maintained in the animal facilities at Antoine Marxer-RBM (Colleretto Giacosa, Italy). In part of the studies, mice were bred and maintained at the animal facilities of the Weizman Institute of Science (Rehovot, Israel).

All animals were handled under sterile conditions and maintained in cage microisolators. Mice to be transplanted were irradiated at 6 to 8 weeks of age with 350 to $375 \mathrm{cGy}$ of total body irradiation from a ${ }^{137} \mathrm{Cs}$ source and then within 24 hours were given a single intravenous injection of: (1) human CD34 ${ }^{+} \mathrm{CB}$ cells, which had been previously separated from several CB samples, then pooled, and cryopreserved (control cells). After thawing, $97 \%$ to $99 \% \mathrm{CD} 4^{+}$cells were viable by trypan blue dye exclusion; (2) cells were harvested from expansion cultures as described. Also the latter cells were cryopreserved and injected at the same time as the control cells. When low numbers of unmanipulated $\mathrm{CD}_{3} 4^{+}$cells were to be transplanted, at least $2 \times 10^{5}$ irradiated $\mathrm{CD}^{-} 4^{-}$cells were coinjected as carrier cells.

Mice were killed 6 to 8 weeks posttransplant for assessment of the number and types of human cells detectable in both femurs, tibias, and spleen. As a control for the frequency of SRC in cryopreserved CD34 ${ }^{+}$ $\mathrm{CB}$ cells, the same numbers of fresh $\mathrm{CD} 34^{+}$cells from pooled $\mathrm{CB}$ samples were injected in similarly pretreated NOD/SCID recipients; the frequency of SRC was not significantly different from that found in cryopreserved $\mathrm{CD} 34^{+}$cells.

Flow cytometric detection of human cells in murine tissues. BM cells were flushed from the femurs and tibias of each mouse to be assessed using a syringe and a 26-gauge needle. To prepare cells for 
flow cytometry, contaminating red blood cells were lysed with $8.3 \%$ ammonium chloride and the remaining cells were then washed in HBSS with $0.1 \%$ bovine serum albumin (BSA; Sigma Chemical Co, Milan, Italy), $0.01 \%$ sodium azide (HFN). The cells were then resuspended at 1 to $2 \times 10^{6}$ cells $/ \mathrm{mL}$ and incubated with mouse IgG (Fluka Chemika Biochemika, Buchs, Switzerland) and with 5\% human serum (HS), to block nonspecific binding to $\mathrm{Fc}$ receptor. Cells were then incubated with monoclonal antibodies (MoAb) specific for human CD45, CD71, and glycophorin-A (GpA), directly labeled with fluorescein isothiocyanate (FITC) or PE (all from Dako A/S, Glostrup, Denmark) for 30 minutes at $4^{\circ} \mathrm{C}$ to assess the total population of human hematopoietic cells. Cells stained with an anti-CD45 conjugated to an R-phycoerythrin-Cy5 tandem conjugate were simultaneously stained with an anti-humanCD34-PE (Becton Dickinson) and CD19-PE (Dako) for quantitation of the total human $\mathrm{CD} 34^{+}$and $\mathrm{CD} 19^{+}$cell populations. In some mice, additional aliquots were stained with anti-human-CD33-PE (Dako), CD41-FITC in combination with anti-human-CD45-Cy5 RPE to allow discrimination of subpopulations within the CD45 gate and with CD71-FITC plus $\alpha$-GpA-PE. ${ }^{30}$ Some cells from each suspension were similarly incubated with irrelevant (control) MoAbs labeled with FITC and PE. Cells from an unmanipulated NOD/SCID mouse were also stained with each of the MoAbs used for detecting positively stained human cells. Only levels of fluorescence which excluded $\geq 99.9 \%$ of all of these negative controls were considered as specific. After staining, all cells were washed once in sodium azide (HFN) containing $2 \mu \mathrm{g} / \mathrm{mL}$ propidium iodide (PI) to allow dead $\left(\mathrm{PI}^{+}\right)$cells to be excluded from analyses. Flow cytometric analysis was performed using a FACScan cytometer (Becton Dickinson). At least 5,000 events were acquired for each analysis. When fluorescent cells represented only a minority of the total population $(\approx 0.1 \%$ ) many more events (at least 20,000$)$ were analyzed.

Hematopoietic cell cultures. Assays for granulopoietic, erythroid, megakaryocytic, and multilineage (granulocyte-erythroid-macrophagemegakaryocyte) colony-forming units (CFU-GM, BFU-E, CFU-Mk, and CFU-GEMM, respectively) were usually performed as follows. For CFU-GM, $1 \times 10^{3} \mathrm{CD} 34^{+} \mathrm{CB}$ cells of the initial cell suspension or suitable aliquots of the stroma-free long-term cultures were cultured at 4 plates per point in 3\% agar, 15\% fetal calf serum (FCS) (HyClone, Logan, UT) in Iscove's Modified Dulbecco Medium (IMDM). For CFU-Mk, the same number of cells was cultured in plasma-clot assay (four dishes per point) as previously described. ${ }^{27}$ For BFU-E and CFU-GEMM, the same number of cells was cultured in $1.3 \%$ methylcellulose (Fluka) and IMDM containing $30 \% \mathrm{FCS}$ at $37^{\circ} \mathrm{C}$ in a humidified atmosphere at $5 \% \mathrm{CO}_{2}$ in air. ${ }^{27}$ Colony scoring was performed on day 12 for CFU-Mk (at the immunofluorescent microscope after staining with an FITC-conjugated MoAb recognizing human GPIIbIIIa) and on day 14 for CFU-GM, BFU-E, and CFU-GEMM. ${ }^{27,28}$ Several growth factors were added at optimum concentrations to sustain the formation of BFU-E and CFU-GEMM: rhuIL-3 (20 ng/mL), rhuGM-CSF (10 $\mathrm{ng} / \mathrm{mL}$ ), rhuEpo $(3 \mathrm{U} / \mathrm{mL})$, and rhuSCF $(50 \mathrm{ng} / \mathrm{mL})$. For CFU-GM, rhuGM-CSF $(20 \mathrm{ng} / \mathrm{mL})$, rhuIL-3 $(20 \mathrm{ng} / \mathrm{mL})$ and rhuSCF $(50 \mathrm{ng} / \mathrm{mL})$ were added. For CFU-Mk, rhuIL-3 $(5 \mathrm{ng} / \mathrm{mL})$ was used as a single growth factor. When transplanted NOD/SCID mouse BM cells were to be evaluated for their human hematopoietic progenitor content, the FCS in the methylcellulose medium was replaced with an equivalent volume of a pretested pool of equivalently supportive normal human serum and bovine plasma in the plasma clot assay was replaced with an equivalent volume of human plasma. Plasma clot assays were adopted not only to detect CFU-Mk colonies (with the addition of rhuIL-3), but for CFU-GM, BFU-E, and CFU-GEMM as well (with the addition of rhuIL-3, rhuGM-CSF, rhuSCF, and rhuEPO). G-CSF was omitted to minimize the stimulation of murine clonogenic cells. These culture conditions have been reported to be selective for colony formation by human progenitors and do not support coexisting murine progenitors. ${ }^{8,13}$ In addition, colonies grown in plasma-clot and colonies plucked from methylcellulose cultures were stained with FITC-conjugated anti-human GPIIbIIIa, CD45, CD13, and GpA and scored at the immunofluorescence microscope. The presence of fluorescent colonies was the index of their human origin. As a control, BM cells from untreated NOD/SCID mice were plated at identical cell concentrations in the same culture assays (plasma clot and methylcellulose) containing only human serum and/or human plasma and the above-reported human-specific growth factors. Dishes were scored from day 12 up to day 21: in these culture conditions no colonies could be detected.

LTC-IC. The LTC-IC content of cell suspension was determined by limiting dilution assays as previously described. ${ }^{27}$ Briefly, 10 to 1,000 purified CD34 ${ }^{+} \mathrm{CB}$ cells at the start of cultures or suitable aliquots of cultured cells were washed and seeded onto preestablished irradiated human BM stromal layers (derived by culturing $10^{7}$ fresh BM MNC in a $\mathrm{T}_{25}$ flask for at least 2 weeks in $5 \mathrm{~mL}$ stromal medium [12.5\% horse serum, $12.5 \%$ FCS, IMDM, 2-mercaptoethanol, $10^{-6} \mathrm{~mol} / \mathrm{L}$ hydrocortisone, and penicillin/streptomycin] and by plating the irradiated [15 Gy] and trypsinized stroma at $7 \times 10^{3} / \mathrm{cm}^{2}$ in 24 -well plates) and maintained at $37^{\circ} \mathrm{C}$ for 5 to 6 weeks with weekly half media changes, at the end of which all cells were harvested and plated for CFC determination in methylcellulose medium. These cultures were incubated at $37^{\circ} \mathrm{C}$ for 2 weeks in the presence of $1.3 \%$ methylcellulose, $30 \%$ FCS, EPO (3 $\mathrm{U} / \mathrm{mL}), \mathrm{IL}-3$ (20 ng/mL), G-CSF (20 ng/mL), GM-CSF (20 ng/mL), and SCF $(50 \mathrm{ng} / \mathrm{mL})$; LTC-IC enumeration was based on the number of CFU-C scored in the limiting dilution assay (LDA).

Stroma-free liquid cultures. Stroma-free expansion cultures were performed as follows. (1) A total of 10 to $20,000 \mathrm{CD} 34^{+} \mathrm{CB}$ cells were cultured in quadruplicate flat-bottomed 24-well plates in $1 \mathrm{~mL}$ of IMDM supplemented with $10 \%$ pooled normal human serum with the following growth factors: FL $(50 \mathrm{ng} / \mathrm{mL})+$ MGDF $(20 \mathrm{ng} / \mathrm{mL})$; SCF $(50 \mathrm{ng} / \mathrm{mL})+\mathrm{FL}(50 \mathrm{ng} / \mathrm{mL})+\operatorname{MGDF}(20 \mathrm{ng} / \mathrm{mL}) ; \mathrm{SCF}(50 \mathrm{ng} / \mathrm{mL})+$ FL $(50 \mathrm{ng} / \mathrm{mL})+$ MGDF $(20 \mathrm{ng} / \mathrm{mL})+\mathrm{IL}-6(10 \mathrm{ng} / \mathrm{mL})$, which were added to each series of microwells twice a week. The wells were grown at $37^{\circ} \mathrm{C}$. At initiation of the cultures, the number of CFC and CFU-Mk present in $1 \mathrm{~mL}$ of a single well was determined by triplicate plasma clot assays. Every week all of the wells were demidepopulated by removal of one half the culture volume (and cells), which was replaced with fresh medium and growth factors. Cells of the harvested media were counted and suitable aliquots of the cell suspensions were assayed for CFC and CFU-Mk content, for immunophenotype analysis $\left(\mathrm{CD} 34^{+}\right.$, $\mathrm{CD}_{3} 4^{+} \mathrm{CD} 38^{-}$) and for LTC-IC determination every 2 to 3 weeks by LDA. The total number of CFC or of LTC-IC generated CFC was calculated as previously reported. ${ }^{27,28}$

(2) In a second series of expansion cultures, the same concentrations of $\mathrm{CD} 34^{+} \mathrm{CB}$ cells were cultured in identical culture conditions (same growth factors and serum). Cultures were set up in quadruplicate. The only difference with the series (1) was that every week, instead of being split in two, the cell suspension of each well was resuspended in twice its volume, split in two, and plated in new 24-well plates. This way every week additional new 24-wells were set up (eg, derived from the 1 $\mathrm{mL}$ prepared at start of cultures, 2, 4, and 8 wells were set up at weeks 2 , 3 , and 4 , respectively).

(3) In this series of experiments, 1 to $5 \times 10^{4} \mathrm{CD} 34^{+}$cells $/ \mathrm{mL}$ were deposited on the bottom of tissue culture $\mathrm{T}_{25}$ or $\mathrm{T}_{75}$ flasks in quadruplicate. Every week the culture volume was doubled. Cell counts were performed every week. At weeks 4, 6, 8, and 12, the immunophenotype of the cells harvested from the different sets of expansion was performed, and the CFC content of each expansion set was determined by seeding suitable aliquots of the pooled wells or flasks in triplicate plasma clot cultures. For LTC-IC assay, limiting dilutions of the cell suspensions deriving from each series of expansion wells or flasks were seeded onto preirradiated stroma layers in 96-well plates for 5 weeks and then the number of CFC generated by methylcellulose cultures was enumerated as described above.

To limit the volume of the expansion cultures, in most experiments, at 
Table 1. Main Characteristics of Injected CB CD34+ Cells and Their Ability to Engraft the BM of NOD/SCID Recipients

\begin{tabular}{|c|c|c|c|c|c|}
\hline \multicolumn{3}{|c|}{ Injected/Mouse } & \multirow{2}{*}{$\begin{array}{c}\text { No. of } \\
\text { Positive Mice }\end{array}$} & \multirow[b]{2}{*}{ Engraftment (\%) } & \multirow[b]{2}{*}{ Human CFC $\left(\times 10^{3}\right)^{*}$} \\
\hline CD34+ Cells & CFC & LTC-IC & & & \\
\hline $2 \times 10^{5}$ & 49,330 & 17,800 & $3 / 3+$ & $12.5,21,7 \ddagger$ & $51.2,98.4,27.6$ \\
\hline $1 \times 10^{5}$ & 24,665 & 8,900 & $4 / 4$ & $1.3,3,11,25$ & $17.7,14.2,41.5,77.6$ \\
\hline $5 \times 10^{4}$ & 12,332 & 4,450 & $4 / 5$ & $1.4,16,3,8,0$ & $N D, 74.9,10.2,36.4,0$ \\
\hline $3.5 \times 10^{4}$ & 8,631 & 3,115 & $4 / 6$ & $1.2,2.3,0,0,1.6,3$ & $4.9,9.8,0,0,8.08,9.5$ \\
\hline $2 \times 10^{4}$ & 4,933 & 1,780 & $3 / 7$ & $0.18,0.5,0.3,0,0,0,0$ & $0.76,2.1,1.9,0,0,0,0$ \\
\hline $1 \times 10^{4}$ & 2,466 & 890 & $0 / 5$ & $0,0,0,0,0$ & $0,0,0,0,0$ \\
\hline
\end{tabular}

$\mathrm{CD} 34^{+}$cells deriving from 6 different $\mathrm{CB}$ samples were separated as described, pooled, and then stored frozen. At the time of injection, the samples were thawed, washed, counted, resuspended in $300 \mu \mathrm{L}$ of IMDM containing $10 \%$ FCS and then injected into 3 to 7 animals as described. $\mathrm{BM}$ of NOD/SCID recipients was recovered from both the femurs and the tibias at week 8 posttransplant.

Abbreviation: ND, not done.

*A total of $1 \times 10^{5}$ to $5 \times 10^{5} \mathrm{BM}$ cells of the transplanted mice were seeded in triplicate dishes for plasma clot assays. Recombinant human IL-3, GM-CSF, SCF, and EPO were added at start of cultures. Dishes were scored after 14 days of incubation, after staining with MoAb as described in Materials and Methods. Only fluorescent colonies were considered of human origin. Values are calculated taking into account that the BM of both femurs and tibias represent $25 \%$ of the total BM.

†Positive mouse $=>0.1 \%$ of human $\mathrm{CD}_{4} 5^{+}, \mathrm{CD} 1^{+}$, and $\alpha-\mathrm{GpA} \mathrm{A}^{+}$cells in the whole BM on FACSscan analysis.

$\ddagger$ Percent of human $\mathrm{CD}_{4} 5^{+}, \mathrm{CD}^{+} 1^{+}$, and $\mathrm{GpA}^{+}$cells in the whole BM on FACSscan analysis.

week $6,7 / 8$ of the total culture volume was cryopreserved and expansion studies were performed with the remaining $1 / 8$. When inocula were to be prepared, $7 / 8$ of week 6 cryopreserved cells were thawed, washed, counted, and grown for an additional 6 to 10 days in the presence of the same media and growth factors previously used; hence, these inocula represented weeks 7 to 8 expanded cells. When weeks 9 to 10 and week 12 expanded cells were to be injected, the $1 / 8$ expanded cells (which had been cryopreserved at weeks 8 and 10, respectively) were thawed, grown for an additional 6 to 10 days and mixed with 7/8 of week 6 cryopreserved cells that had been thawed and grown as previously described. The two samples were mixed, washed, and resuspended in a small aliquot and injected in mice.

For limiting dilution studies, the $1 / 8$ cells expanded for 6 and 8 weeks (and then cryopreserved) were thawed and grown for an additional 6 to 10 days before being injected into mice. In these experiments, the cells were not mixed with $7 / 8$ of week 6 cryopreserved cells; hence they represented the first dilution (1/8 of initial $\mathrm{CD} 34^{+}$cells). The next dilutions were prepared from the $1 / 8$ cells $(1 / 16,1 / 32$, etc).

DNA extraction and analysis of human cell engraftment. High molecular weight DNA was extracted from the BM of transplanted mice by phenol-chloroform extraction using standard protocols. DNA was digested with EcoRI and separated by agarose gel electrophoresis, transferred onto a positively charged nylon membrane, and probed with a labeled human chromosome 17-specific $\alpha$-satellite probe (p17H8) (limit of detection, approximately $0.05 \%$ human DNA). To quantify the level of human cell engraftment, the intensity of the characteristic 2.7-kb band in samples was compared with those of human: mouse DNA control mixtures $(0 \%, 0.1 \%, 1 \%, 10 \%$ human DNA).

Statistical analysis. For purposes of LDAs (LTC-IC and SRC), Poisson statistics for the single-hit model were applied. The frequency of LTC-IC and SRC in cell suspensions was calculated using maximum likelihood estimator. ${ }^{32}$

\section{RESULTS}

Groups of sublethally irradiated NOD/SCID mice were injected with decreasing concentrations of $\mathrm{CD} 34^{+} \mathrm{CB}$ cells, which had been previously separated from several CB samples, then pooled, and stored frozen until the time of transplant. Six to 8 weeks after inoculation, BM cells of the sacrificed animals were obtained from both femurs and both tibias and assessed for the presence of human hematopoietic cells. Table 1 presents a summary of these data. While $2 \times 10^{5}$ and $1 \times 10^{5} \mathrm{CD} 34^{+}$cells

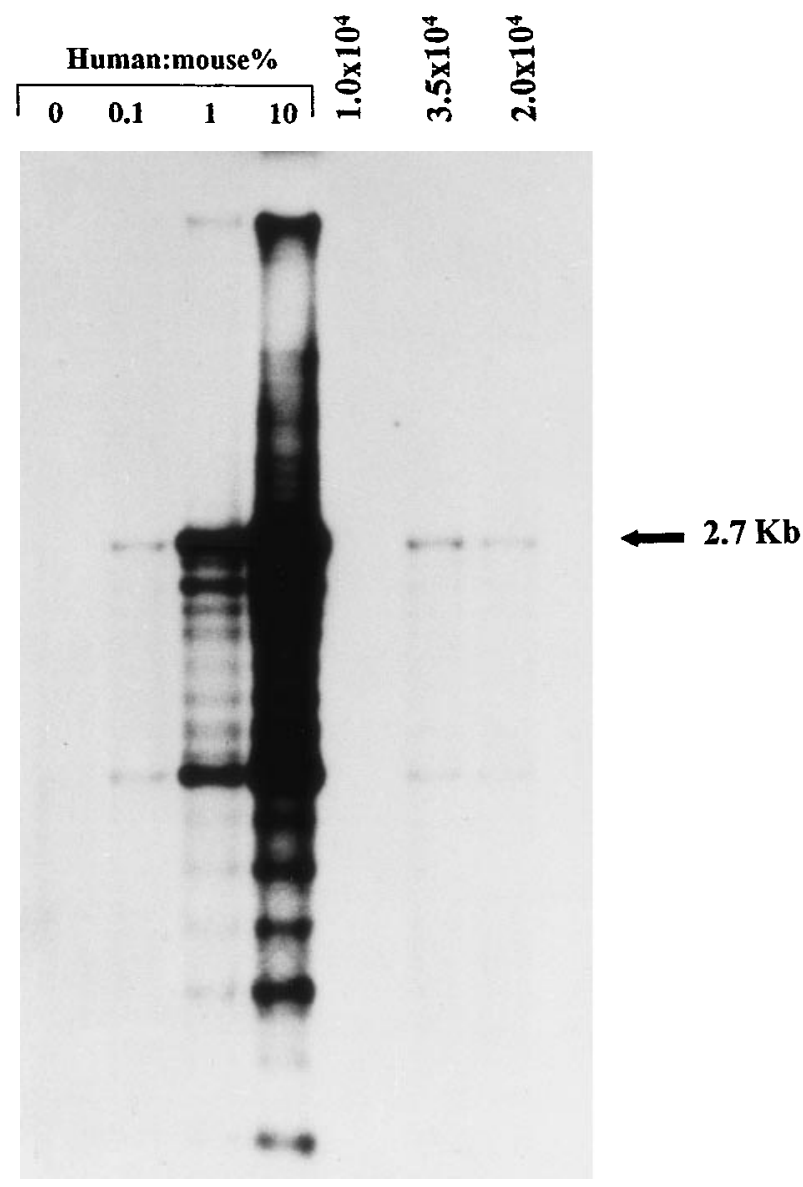

Fig 1. Representative DNA analysis of human cell engraftment in the BM of NOD/SCID mice transplanted with $1 \times 10^{4}, 2 \times 10^{4}$, and $3.5 \times 10^{4}$ unmanipulated CD34+ CB cells. Cells were injected together with preirradiated $2 \times 10^{5} \mathrm{CD} 34^{-} \mathrm{CB}$ cells as carrier cells. Human DNA was assessed by Southem analysis using a human chromosome 17-specific $\alpha$-satellite probe. Human:mouse controls are given as percent human DNA. 

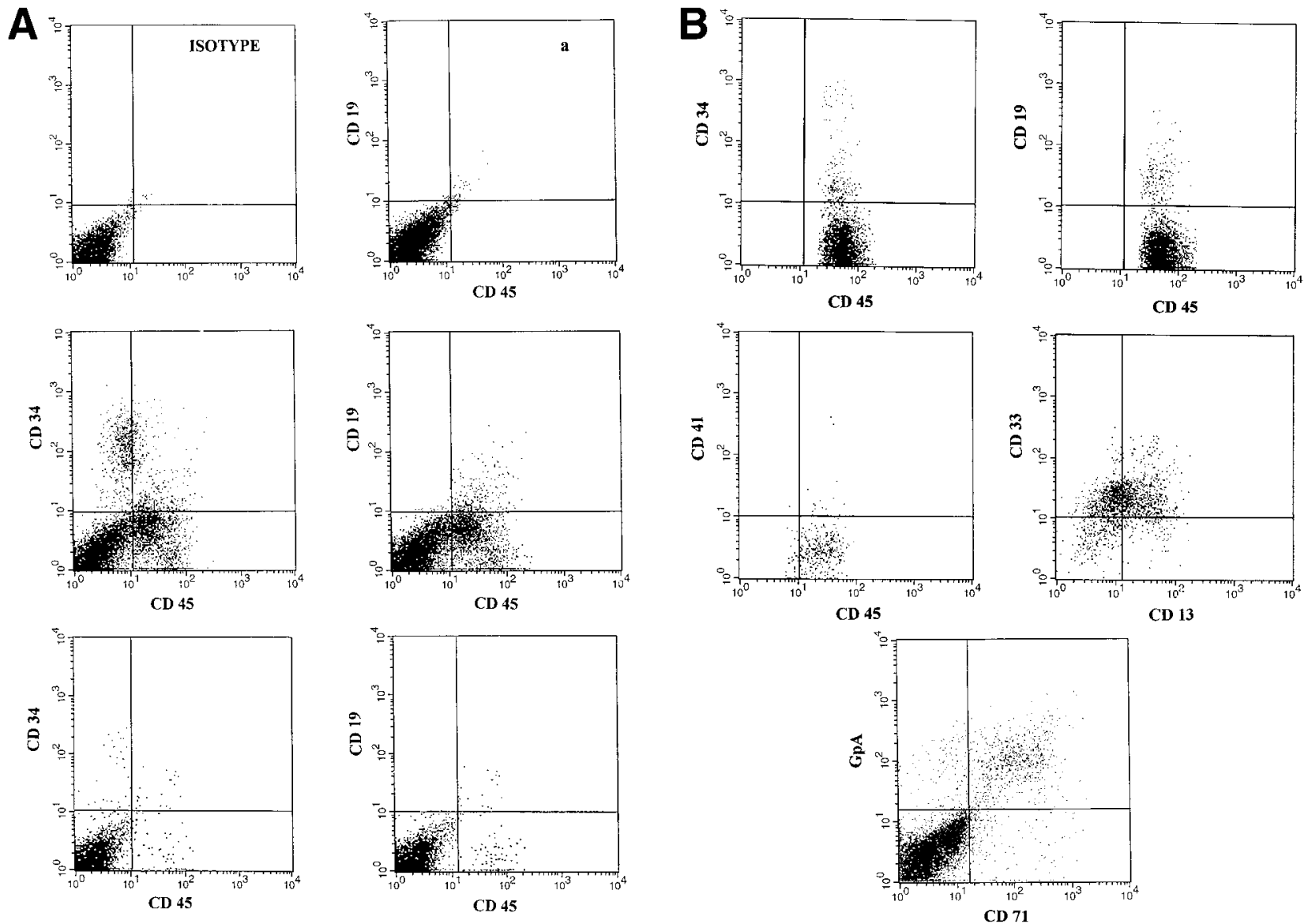

Fig 2. (A) Representative fluorescence-activated cell sorting (FACS) profiles of marrow cells from NOD/SCID mice transplanted 8 weeks previously with unmanipulated CD34+ CB cells. (a) Negative control: a nonengrafted mouse (transplanted with $2 \times 10^{5}$ irradiated CD34- CB carrier cells). (Middle) A mouse transplanted with $1 \times 10^{5}$ CD34+ CB cells. (Bottom) A mouse transplanted with $2 \times 10^{4}$ CD34 $4^{+}$cells. CD45/CD34 and CD45/CD19 analysis was performed on total BM cells. (B) Multilineage engraftment in the BM of a representative mouse transplanted with $1 \times 10^{5}$ unmanipulated CD34+ CB cells. Analysis of lineage markers (CD45/CD34, CD19, CD41, and CD13/CD33) was performed on cells comprised within the CD45 gate. Analysis of GPA/CD71-positive cells was performed on total BM cells.

Table 2. Comparison Between Three Different Expansion Protocols

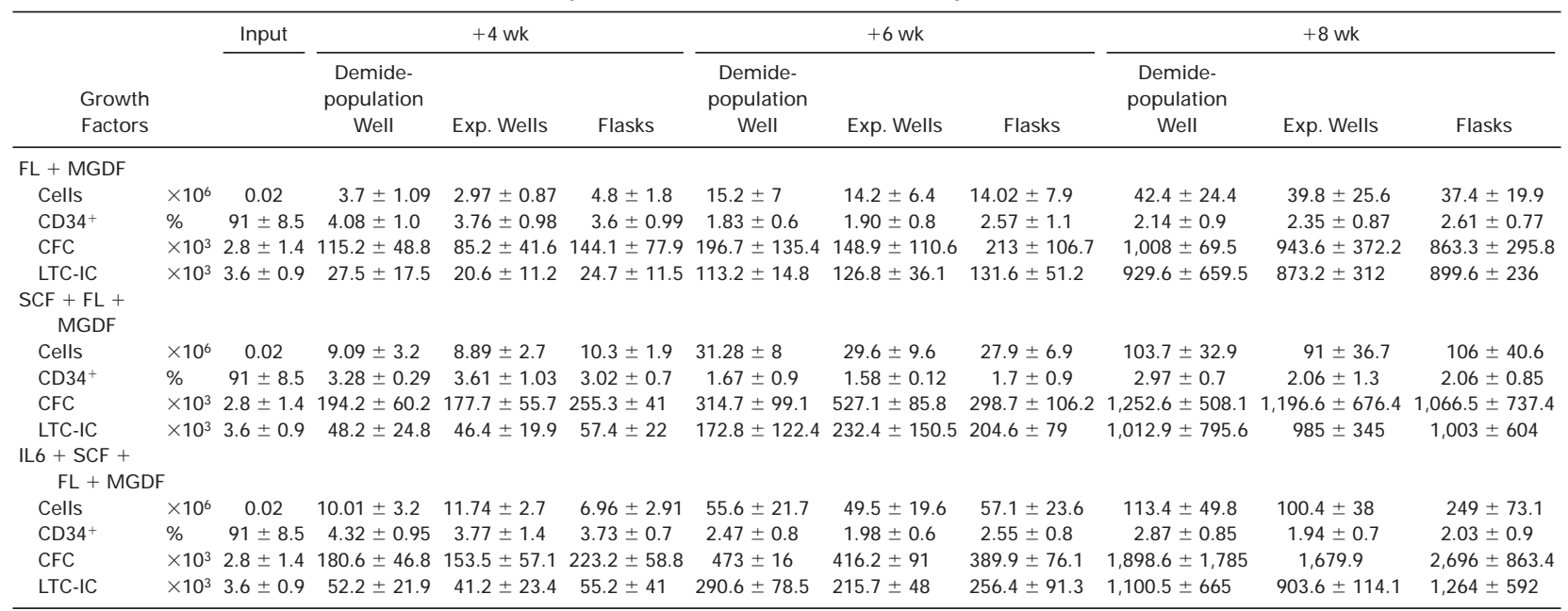

Twenty thousand CB CD34+ cells were resuspended in $1 \mathrm{~mL}$ IMDM containing $10 \%$ pooled human serum and cultured for up to 8 weeks in 24 -well plates. In the first series (demidepopulation wells) cells in $1 \mathrm{~mL}$ of a single well were demidepopulated every week by removal of one half the culture medium (and cells), which was replaced with the same volume of fresh medium and growth factors. In the second series (expansion wells), $2 \times 10^{4}$ CD34+ cells were prepared as described above in 24 -well plates in $1 \mathrm{~mL}$. Every week the cells were resuspended in twice the volume of culture medium, so that every week additional new 24-wells were set up. In the third series (flasks) $2 \times 10^{4} \mathrm{CD} 34^{+}$cells $/ \mathrm{mL}$ were layered on the bottom of T flasks and every week the culture volume was doubled. At the indicated time points, the cells were harvested, counted, and aliquots analyzed for $\mathrm{CD}_{4} 4^{+}$antigen expression. Suitable aliquots were assayed in semisolid assays for CFC and on stroma cocultures for LTC-1C enumeration. Mean \pm SEM of 4 to 6 separate experiments performed in quadruplicate. 
Table 3. Antigenic Composition of CD34+ CB Cells at Initiation of Liquid Cultures and at Various Time Intervals During Ex Vivo Expansion

\begin{tabular}{|c|c|c|c|c|c|c|c|c|c|c|c|c|}
\hline $\begin{array}{l}\text { Culture } \\
\text { Conditions }\end{array}$ & CD34 & CD38 & $\mathrm{CD} 34^{+} 38^{-}$ & CD33 & CD13 & $\mathrm{CD} 33^{+} 13^{+}$ & CD14 & CD2 & CD19 & CD41 & $\alpha \mathrm{GpA}$ & CD71 \\
\hline Start & $91 \pm 8.5$ & $94 \pm 3.1$ & $0.95 \pm 0.05$ & $49 \pm 6.4$ & 0 & 0 & $0.3 \pm 0.03$ & $2.0 \pm 1.6$ & $1.8 \pm 1.1$ & $0.4 \pm 0.2$ & $4.1 \pm 1.6$ & 0 \\
\hline wk 4 & $3.9 \pm 0.4$ & $76 \pm 4.8$ & $0.18 \pm 0.04$ & $96 \pm 13$ & $94.7 \pm 7.8$ & $91 \pm 11.6$ & $59 \pm 7.1$ & $0.25 \pm 0.04$ & $0.9 \pm 0.2$ & $3 \pm 1.4$ & $5 \pm 2$ & $2 \pm 2$ \\
\hline wk 8 & $2.1 \pm 0.17$ & $27 \pm 7$ & $0.6 \pm 0.15$ & $32 \pm 9.6$ & $1.72 \pm 16.4$ & $1.7 \pm 0.3$ & $25 \pm 1.4$ & $0.12 \pm 0.01$ & $0.07 \pm 0.01$ & $0.5 \pm 0.01$ & $0.3 \pm 0.01$ & $2.63 \pm 1.6$ \\
\hline wk 12 & $2.3 \pm 1$ & $34 \pm 11$ & $0.46 \pm 0.9$ & $85.4 \pm 2.4$ & $7.2 \pm 4.3$ & $7.1 \pm 2.7$ & $36.3 \pm 2.1$ & $0.1 \pm 0$ & $0.19 \pm 0.03$ & $0.18 \pm 0.6$ & $0.56 \pm 0.04$ & $13.1 \pm 2.9$ \\
\hline
\end{tabular}

Positive cells (\%) of each subpopulation. Mean \pm standard deviation (SD) from four to seven separate experiments performed in replicate wells for each growth factor combination at different time points.

engrafted the totality of mice, 35,000 and $20,000 \mathrm{CD} 34^{+}$cells engrafted 4 of 6 and 3 of 7 mice, respectively. No mouse was found to be engrafted by $10,000 \mathrm{CD} 34^{+}$cells. The level of engraftment was variable and dependent on the number of injected $\mathrm{CD}_{4} 4^{+}$cells (human $\mathrm{CD} 45^{+}, \mathrm{CD} 71^{+}$, and $\alpha-\mathrm{GpA}^{+}$ cells ranged from $0.18 \%$ to $25 \%$ ). The level of human engraftment was also evaluated by DNA analysis (as shown in Fig 1). The frequency of SRC in the unmanipulated cryopreserved $\mathrm{CD} 34^{+} \mathrm{CB}$ cells was found to be 1 in $30,900 \mathrm{CD} 34^{+}$cells $(95 \%$ confidence interval $1: 53,600$ to $1: 17,800)$. It was similar to that of fresh CD34 ${ }^{+} \mathrm{CB}$ cells (1 in 29,800; 95\% confidence interval $1: 51,700$ to $1: 17,300)$. BM cells of engrafted mice were further analyzed for evidence of multilineage development from input $\mathrm{CD} 4^{+}$cells. Cells within the huCD45 gate or costained with CD45 were quantified for myeloid and lymphoid surface markers as well as for the expression of the CD34 antigen. Erythroid and megakaryocyte surface marker expression was also investigated. Figure $2 \mathrm{~A}$ and $\mathrm{B}$ shows representative analysis of BM cells from engrafted and nonengrafted mice. As an additional proof of human myeloid engraftment, BM cells of sacrificed mice were cultured in semisolid assays in culture conditions that have been reported to allow human and not mouse colony growth. ${ }^{8,13}$ In addition, colonies were stained with MoAbs recognizing human total leukocytes, granulocytemacrophages, erythroid cells, and megakaryocytes and only fluorescent colonies (consisting of human cells) were counted (Table 1).

In the second part of our study, $\mathrm{CB} \mathrm{CD} 34^{+}$cells were cultured in vitro in stroma-free liquid cultures as described. ${ }^{27,28}$ Cell counts, CD $34^{+}, \mathrm{CD} 34^{+} 38^{-}$subpopulations, CFC output, and LTC-IC expansion obtained in the different settings were compared. At weeks 4, 6, and 8 of expansion cultures, all cells were harvested from quadruplicate cultures, counted, and subjected to the same screening (immunophenotype analysis, CFC output, and LTC-IC enumeration) as described before. All of the remaining cells (in 7.5 to $127 \mathrm{~mL}$ ) were washed, cryopreserved, and stored frozen for further injection into sublethally irradiated NOD/SCID recipients (one mouse for each expansion).

Evident from these experiments is the finding that only marginal differences could be detected in the qualitative and quantitative content of the three different expansion procedures (Table 2). After a 4-week expansion in the presence of FL+MGDF, cell counts ranged from 148-fold to 240-fold the initial number; with SCF+FL+MGDF, the cell count was 444-fold to 515-fold the input cells; the four-factor combination

Table 4. Comparison Between Cell Number, CFC, and LTC-IC Injected and Ability to Engraft the BM and the Spleen of NOD/SCID Mice by Human CB Cells Cultured in Stroma-Free Cultures for 4 Weeks

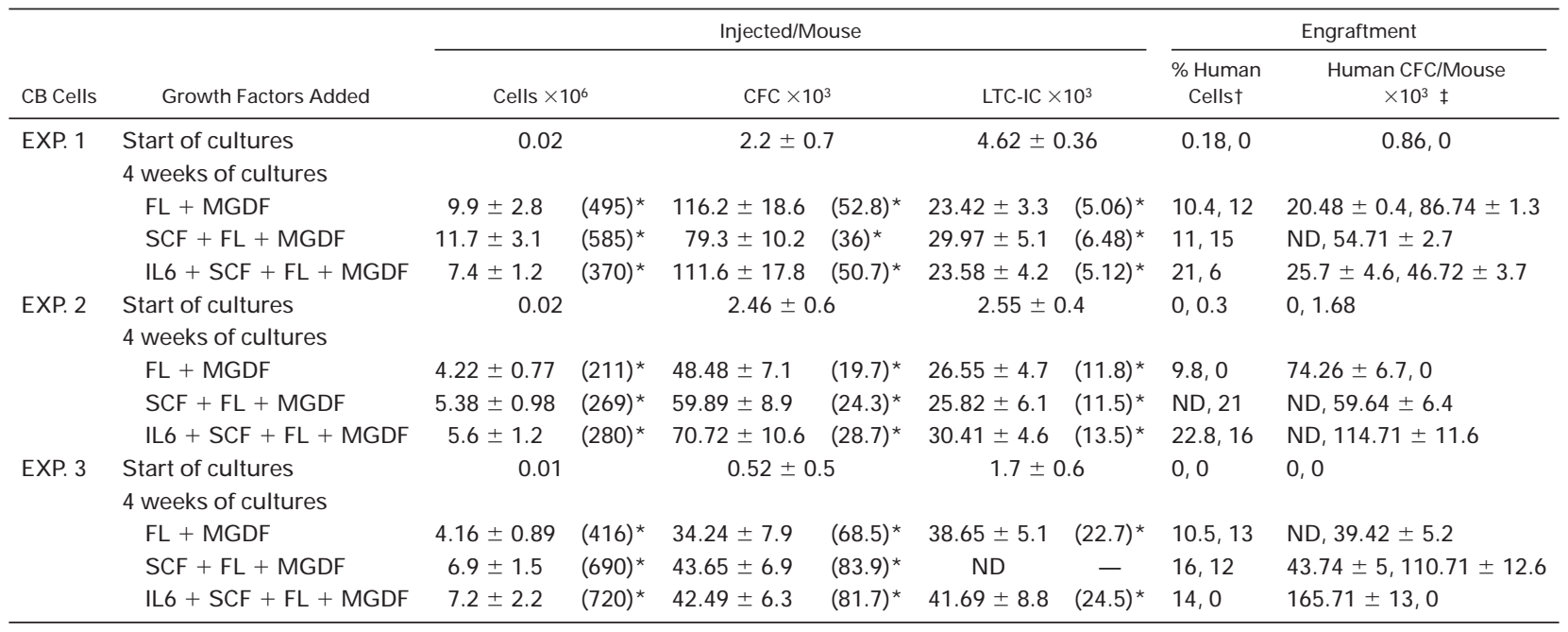

$\mathrm{CD}^{+} 4^{+}$cells were cultured at $10 \times 10^{3} / \mathrm{mL}$ or $20 \times 10^{3} / \mathrm{mL}$ in 24 -well plates as described. Cells at the start of cultures and cells harvested after 4 weeks of suspension cultures were cryopreserved and kept frozen until the time of injection in NOD/SCID mice. The expansion cultures were performed in quadruplicate. Two mice were injected each with 20,000 or 10,000 uncultured cells and two mice each with the content of a single expansion culture.

*Fold increase (compared with the input value).

†Each value represents the percentage of human $\mathrm{CD} 45^{+}, \mathrm{CD} 71^{+}$, and $\alpha-\mathrm{GpA}{ }^{+}$cells detected in the BM of each individual mouse.

$\ddagger$ Mean \pm SEM of the number of human CFU-GM + BFU-E + CFU-GEMM + CFU-Mkgenerated by plating $1 \times 10^{5}$ to $5 \times 10^{5}$ BM cells of engrafted NOD/SCID mice (at least three dishes per point), taking into account that BM cells of femurs and tibias represent $25 \%$ of the total BM. 
CB EXPANSION AND ENGRAFTMENT

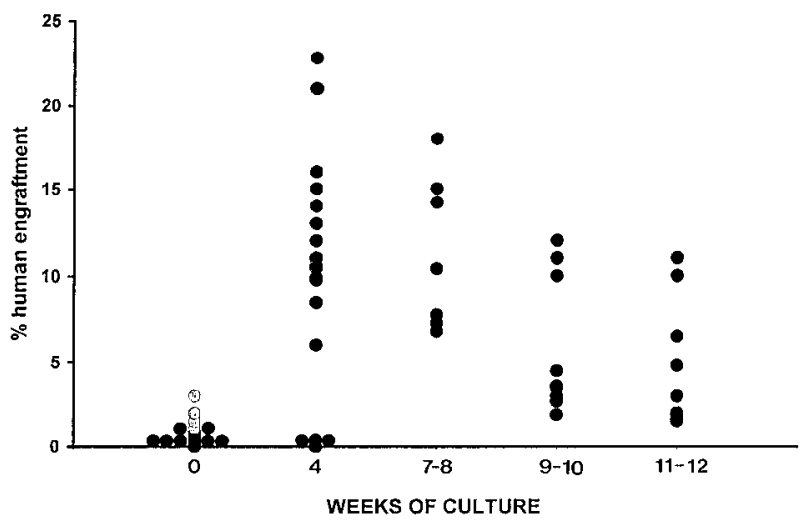

Fig 3. Engraftment of human $\mathrm{CB}$ CD34 ${ }^{+}$cells at start of cultures and of their progeny after 4 to 12 weeks of expansion. The level of human engraftment was evaluated by flow cytometry by determining the percent of human $\mathrm{CD}^{+} 5^{+}, \mathrm{CD}^{+}$, and $\mathrm{GPA}^{+}$cells within the total BM cells in individual NOD/SCID mice. Each animal was injected either with unmanipulated CD34+ CB cells $\left(2 \times 10^{4}, 0 ; 3.5 \times 10^{4}, \bigcirc\right)$ either with the cells generated by initial $2 \times 10^{4}$ or $3.5 \times 10^{4} \mathrm{CD}^{4} 4^{+}$ cells after 4, 7 to 8, 9 to 10 or 12 weeks of cultures as described in Materials and Methods. Each circle represents an individual mouse.

appeared also most effective in inducing and maintaining a sustained cell production (348-fold to 587-fold) and CFC output (55-fold to 80-fold). Expansion of the LTC-IC population was induced to a very similar degree by all three growth factor combinations and in all three culture settings (Table 2). Also, at weeks 6 and 8 of expansion cultures, cell number, percent of $\mathrm{CD} 4^{+}$cells, as well as CFC production and LTC-IC expansion, were not much different if demidepopulated and expanded wells or flasks were compared (Table 2). Table 3 shows the proportion of different hematopoietic subpopulations at start of cultures and at different time points of expansion. No differences could be detected in the cellular composition of the cells expanded with the three growth factor combinations (not shown).

To determine whether the expanded cells retained their ability of full hematopoietic reconstitution (ie, sustained and multilineage engraftment) cohorts of 6- to 8-week-old NOD/ SCID mice were irradiated with 350 to $375 \mathrm{cGy}$ from a ${ }^{137} \mathrm{Cs}$ source and, within 24 hours, injected with either 35,000, 20,000 , or $10,000 \mathrm{CD} 34^{+} \mathrm{CB}$ cells, which were cryopreserved at the start of cultures, or the progeny of identical numbers of $\mathrm{CD} 4^{+}$cells that were grown for 4 weeks with FL+MGDF, $\mathrm{SCF}+\mathrm{FL}+\mathrm{MGDF}$, IL-6+SCF+FL+MGDF (one mouse for each expansion). Six to 8 weeks later, BM cells of all mice were prepared, counted, and subjected to DNA and phenotype analysis to determine whether or not human cells were present; which subpopulation was represented and whether human hematopoietic progenitors (BFU-E, CFU-GM, CFU-GEMM) could be detected. Table 4 shows the results of three separate experiments performed in quadruplicate.

In keeping with the results reported in Table 1, only 2 of 6 mice that had been injected with 20,000 or 10,000 cryopreserved uncultured CD34 ${ }^{+} \mathrm{CB}$ cells were engrafted and the level of human engraftment was very low. These data were confirmed by subsequent DNA analysis: the results obtained by injecting an additional 13 mice with 35,000 and 20,000 unmanipulated
$\mathrm{CD} 4^{+}$cells are shown in Fig 3. The same figure, Fig 4 and Table 4 show that, at the opposite side, mice injected with the cells that had been generated by the same number of initial $\mathrm{CD} 34^{+} \mathrm{CB}$ cells in 4-week expansion cultures supported by $\mathrm{FL}+\mathrm{MGDF}, \mathrm{SCF}+\mathrm{FL}+\mathrm{MGDF}$, and IL6+SCF+FL+MGDF engrafted the vast majority (15 of 18) of NOD/SCID mice, although at a variable degree. Human $\mathrm{CD} 45^{+}, \mathrm{CD}^{+} 1^{+}$, and $\mathrm{GpA}^{+}$cells constituted $6 \%$ to $23 \%$ of the entire BM. Further analysis of the engrafted $\mathrm{BM}$ cells showed the consistent presence of human $\mathrm{CD} 45^{+} \mathrm{CD} 19^{+}$and $\mathrm{CD} 45^{+} \mathrm{CD} 34^{+}$cells. $\mathrm{CD}_{3}{ }^{+}, \mathrm{CD}_{4} 1^{+}, \mathrm{CD}_{71}{ }^{+}$, and $\mathrm{GpA}^{+}$cells were also represented (not shown). Plasma clot assays performed by seeding BM cells of transplanted NOD/SCID mice showed that human CFU-GM, BFU-E, CFU-GEMM, and CFU-Mk were indeed present (Table 4). Colonies grown in plasma-clot assays were scored at the immunofluorescent microscope after being stained with FITCconjugated anti-human CD41, CD45, CD13, and $\alpha-\mathrm{GpA}$ antibodies. All of the colonies were positive, thus indicating their human origin.

Expansion cultures were then extended for up to 12 weeks. Flow cytometry analysis of the cells harvested at different time points did not show substantial differences in the CD34 expression of the cells grown in the presence of the three growth factor combinations. $\mathrm{CD}^{+} 4^{+}$cells still constituted a good
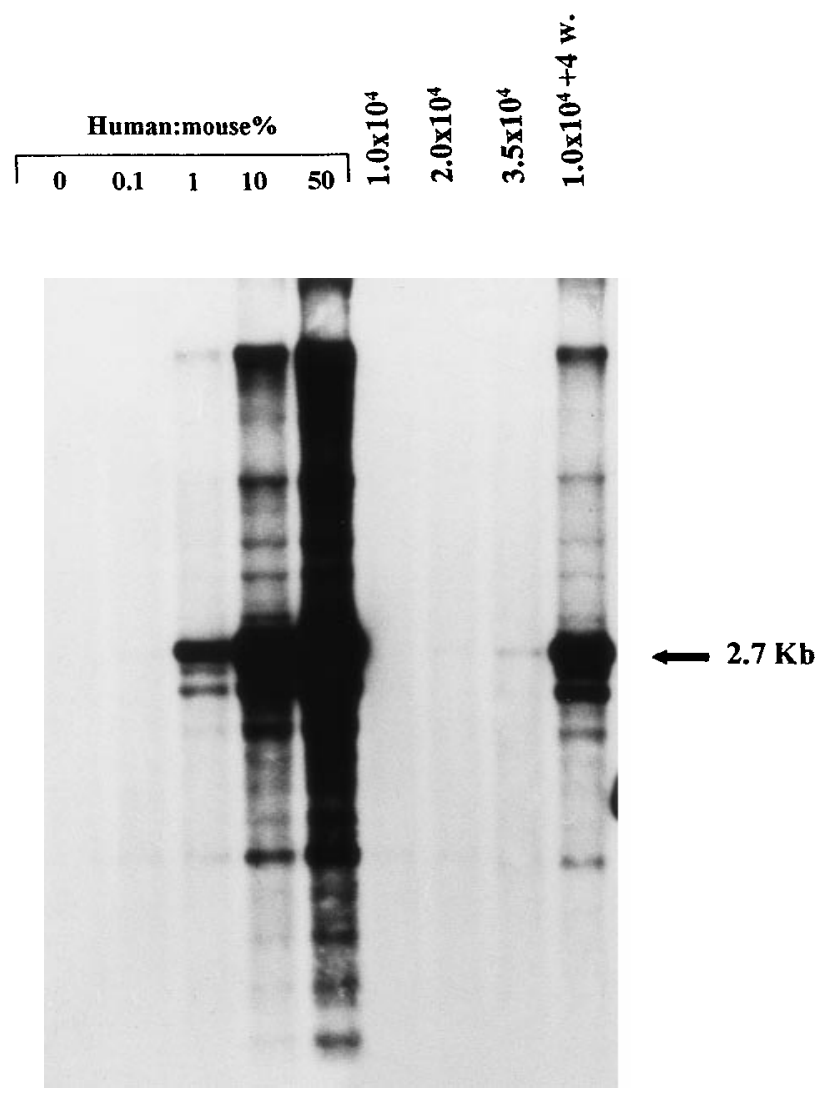

Fig 4. Representative Southem blot analysis of individual NOD/ SCID mice transplanted with $1 \times 10^{4}, 2 \times 10^{4}$, and $3.5 \times 10^{4}$ unmanipulated CD34+ $\mathrm{CB}$ cells and with week 4 expanded cells (deriving from $1 \times 10^{4}$ initial CD34+ cells). DNA was extracted from the murine BM at week 8 after transplant and hybridized with a human chromosome 17-specific $\alpha$-satellite probe. 
proportion of the total cell population ( Fig 5). CD34 ${ }^{+} \mathrm{CD}^{-} 8^{-}$ cells were also detected (Fig 6).

Cells cultured for 6 to 7 weeks engrafted the vast majority of injected mice (Fig 3). Both DNA analysis and flow cytometry performed on BM cells of the transplanted mice showed that human cells were indeed detectable. $\mathrm{CD} 45^{+}, \mathrm{CD} 71^{+}$, and $\mathrm{GpA}^{+}$cells accounted for up to $20 \%$ of the entire BM after 7 to 8 weeks of liquid cultures; human engraftment was detectable at fairly good levels (up to $10 \%$ ) in mice injected with cells expanded for up to 12 weeks. Further flow cytometry analysis of the BM cells of the engrafted mice showed that all of the different hematopoietic lineages were represented (Fig 7A and
B). In addition, human colonies were detected in semisolid cultures prepared with BM cells of mice transplanted with expanded CB cells (Table 5). Expansion studies performed beyond the week 6 cryopreservation comprised only one eighth of the initial CD34+ cells; this is why we first inoculated the expanded $1 / 8$ together with the cryopreserved $7 / 8$ (hence the engraftment activity might be due completely to the latter). Therefore, to better define whether weeks 7 to 8 and week 10 expanded cells contained SRC and to quantitate the extent of the amplification of the in vivo repopulating cells in the expansion cultures, the $1 / 8$ cells expanded for 7 to 8 and 9 to 10 weeks were injected into sublethally irradiated NOD/SCID recipients
Fig 5. Analysis of CD34 antigen expression on CB CD34+ cells at start of cultures (week 0 ) and at weeks $4,6,8$, and 12 of ex vivo expansion in stroma-free cultures supplemented with FL+ MGDF and IL6+SCF+FL+MGDF.

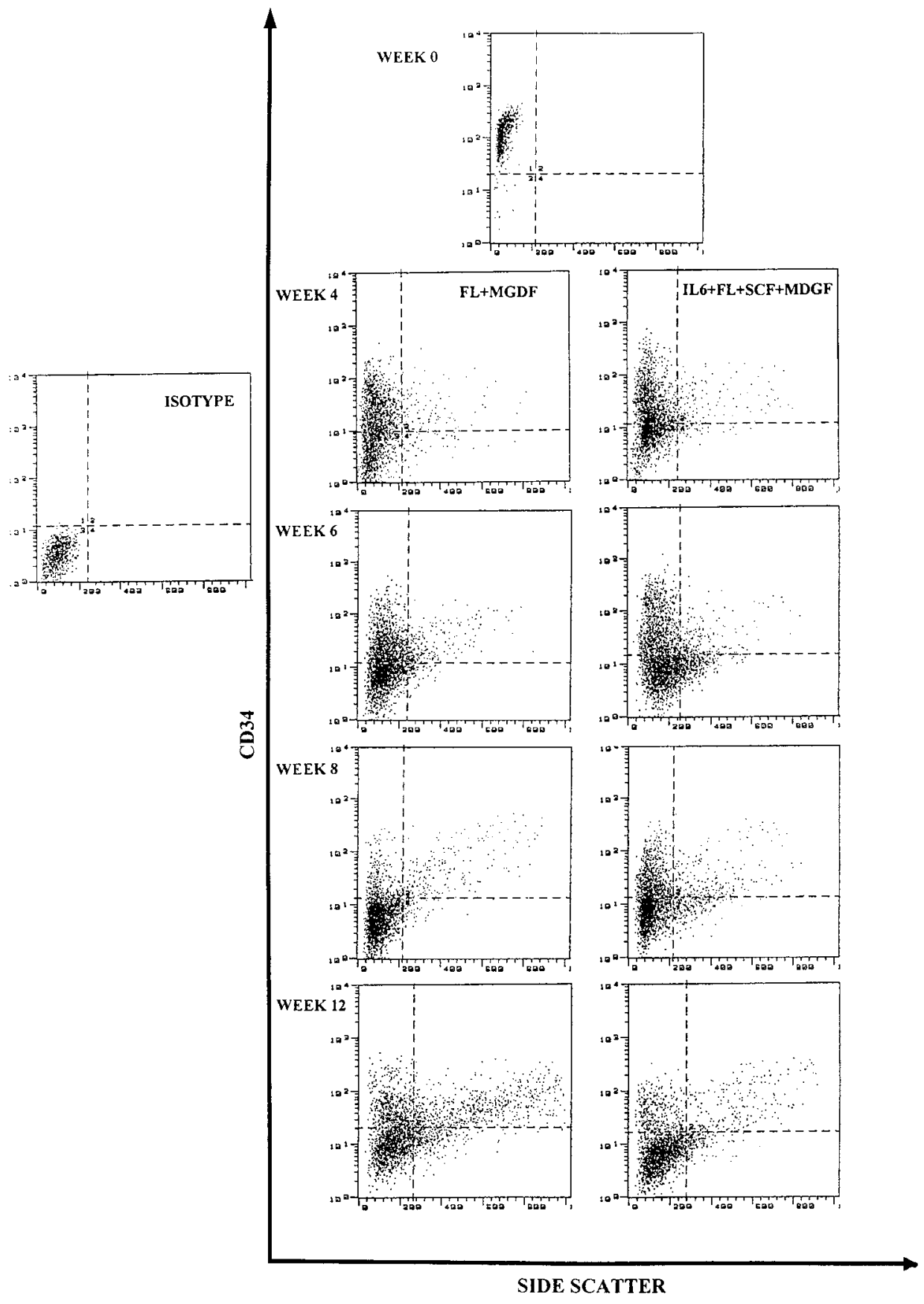




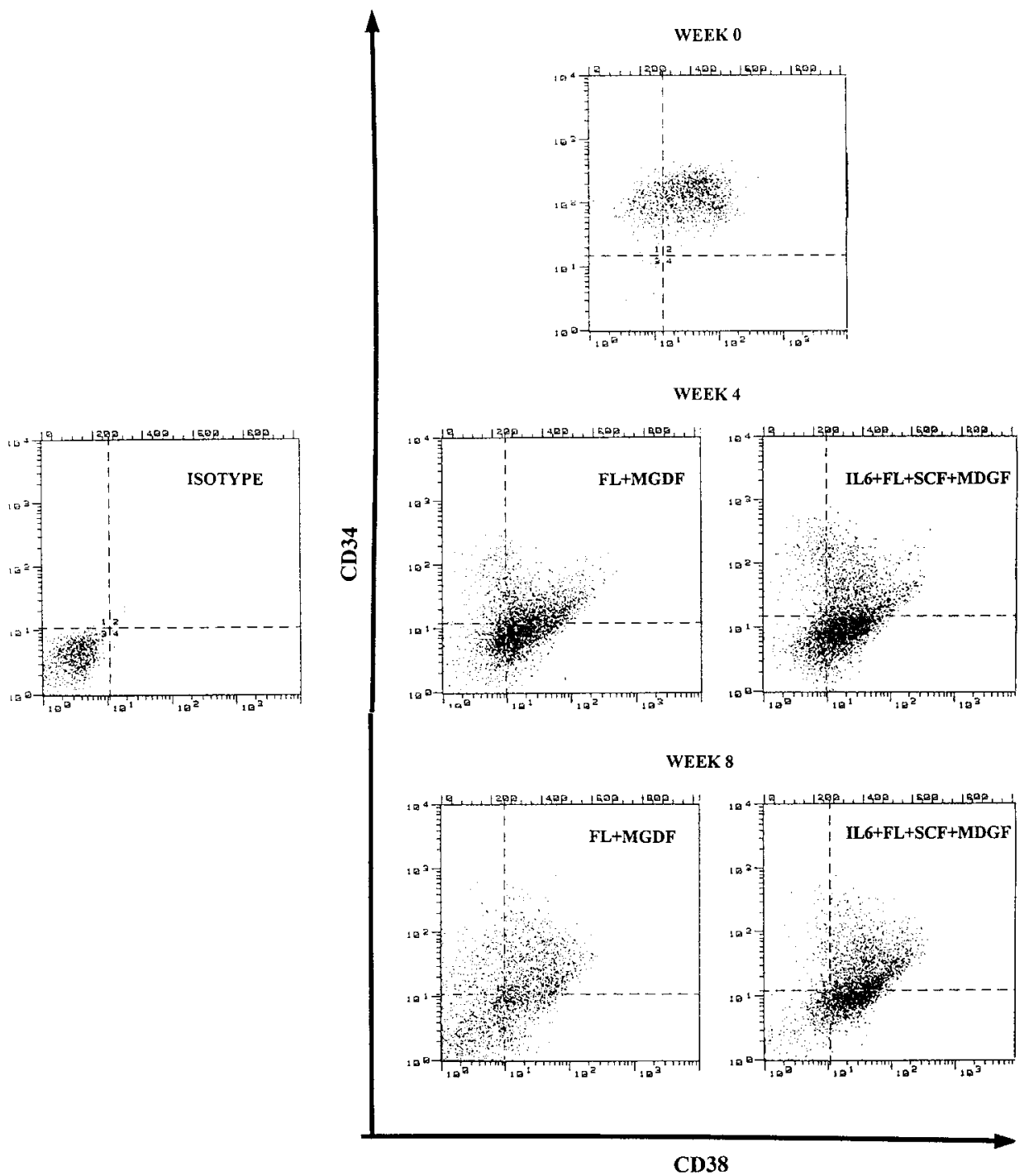

CD38
Fig 6. Analysis of CD34 and CD38 antigen expression on CD34+ $\mathrm{CB}$ cells at start of cultures (week 0 ) and after 4 and 8 weeks of expansion in stroma-free cultures supplemented with FL+ MGDF and IL6+SCF+FL+MGDF. without further mixing with the remaining $7 / 8$ and were considered to represent the first dilution. Taking into account the number of the $\mathrm{CD} 34^{+}$cells at the start of cultures $(50,000$, $35,000,20,000$, or $10,000 \mathrm{CD}^{+} 4^{+}$cells), the number of the initial cells injected per mouse was calculated (eg, 1/8 of the cells expanded by 20,000 initial $\mathrm{CD} 34^{+}$cells represents the corresponding initial $2,500 \mathrm{CD} 34^{+}$cells; $1 / 16$ of initial 20,000 cells represents 1,250 cells, and so on). Shown in Table 5 are the results of two separate experiments performed in quadruplicate and injected in replicate mice (two per cell dose). BM cells of the injected recipients contained human cells. The degree of human engraftment in mice injected with cells expanded for 7 to 8 weeks ranged between $6.8 \%$ and $18 \%$. In particular, BM cells of engrafted mice when cultured in semisolid assays specific for human progenitors, generated colonies (CFU-GM, CFU-Mk, and BFU-E), which were positively stained by human specific MoAbs. The experiments reported in Table 5 and additional limiting dilution experiments reported in Fig 8 showed that the cells generated after 7 to 8 weeks of expansion by initial 1,250 , 625 , and $312 \mathrm{CD}^{2} 4^{+}$cells repopulated 9 of 10,7 of 10 , and 8 of 14 mice, respectively. Also, Figs 9 and 10 show that after 9 to 10 weeks of expansion, the cells obtained by initial $1,560 \mathrm{CD} 34^{+}$ cells engrafted 7 of 7 mice, those obtained by $625 \mathrm{CD} 34^{+}$cells engrafted 5 of 7 mice, and those deriving from $312 \mathrm{CD}^{+} 4^{+}$cells engrafted 7 of 12 mice.

Poisson statistics allowed us to calculate that the frequency of SRC after 7 to 8 weeks of expansion was 1 in 471 initial CD $34^{+}$ cells (95\% confidence interval 1:571 to 1:296), while, after 9 to 10 weeks, it was 1 in 393 initial CD34+ cells $(95 \%$ confidence interval 1:678 to $1: 228)$.

\section{DISCUSSION}

The development of SRC assay for primitive human hematopoietic cells capable of repopulating the BM of NOD/SCID immune deficient mice with myeloid and lymphoid lineages provides a new approach to investigate the organization of the human hematopoietic system and to characterize primitive stem cells. The experiments reported here show that $\mathrm{CB} \mathrm{CD} 34^{+}$cells after a 4- to 10-week expansion in stroma-free liquid cultures containing the combinations of a few growth factors $(\mathrm{FL}+\mathrm{MGDF} \pm \mathrm{SCF} \pm \mathrm{IL}-6)$ retained their capacity to completely engraft the BM of sublethally irradiated NOD/SCID 

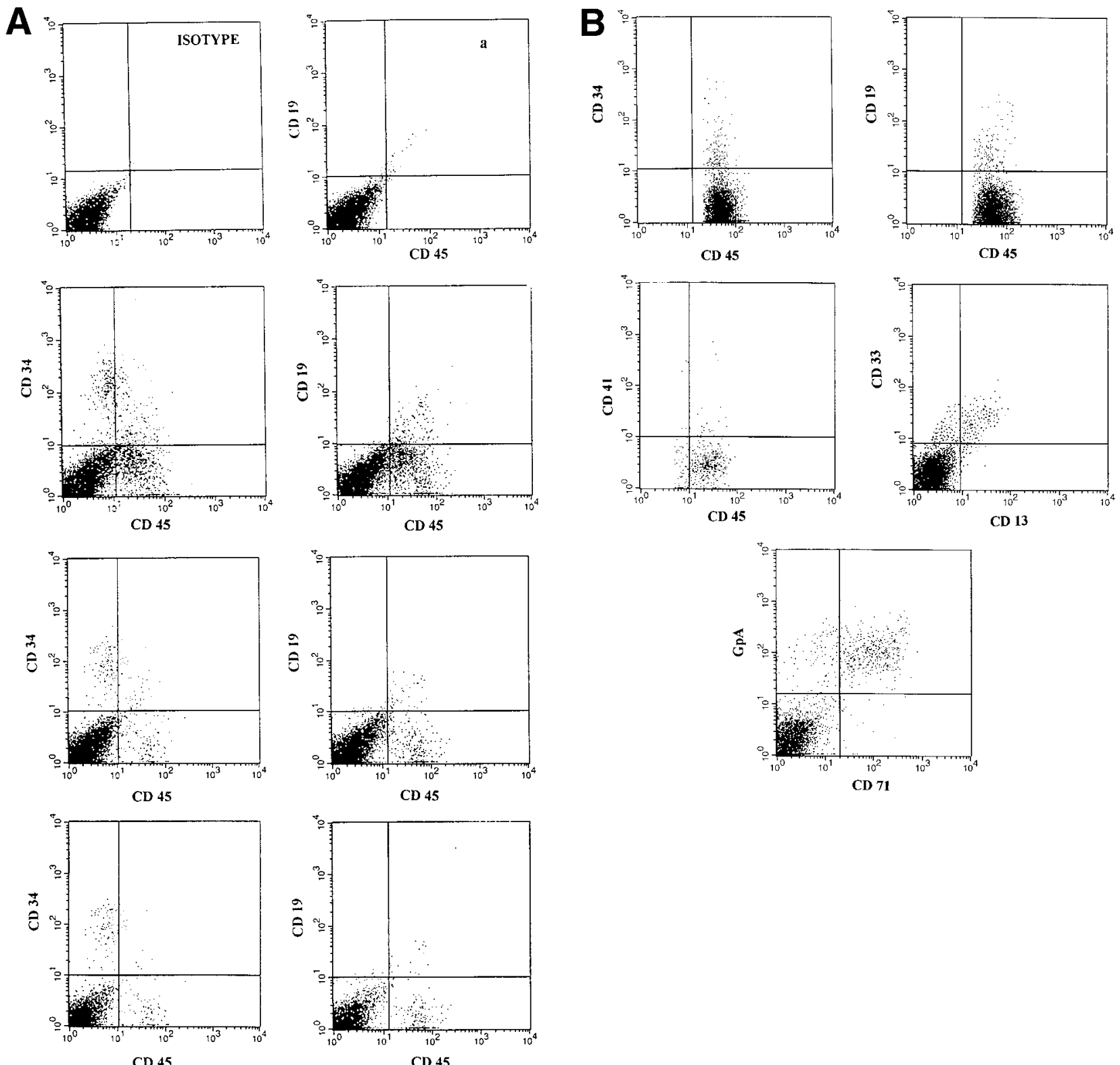

Fig 7. (A) Representative FACS profiles of marrow cells from individual NOD/SCID mice transplanted 8 weeks previously with cells deriving from $3.5 \times 10^{4} \mathrm{CD} 34^{+}$CB cells after a 10-week expansion in stroma-free cultures containing IL-6, SCF, FL and MGDF. From top to bottom: isotype control and (a) a nonengrafted mouse. Human CD45/CD34 and CD45/CD19 in the BM cells of a mouse transplanted with 1/8, 1/25, and 1/70 of the cell progeny deriving from $3.5 \times 10^{4}$ initial CD34+ cells. CD45/CD34 and CD45/CD19 analysis was performed on total BM cells. (B) Multilineage engraftment in the BM of a representative mouse transplanted with week 10 expanded cells (deriving from $2 \times 10^{4}$ initial CD34+ cells). Analysis of lineage markers (CD45/CD34, CD19, CD41, and CD13/CD33) was performed on cells comprised within the CD45 gate. Analysis of GpA/CD71 cells was performed on total BM cells.

recipients. The level of engraftment, well above that usually observed when the same number of uncultured cells were injected in the same recipients, suggested that SRC were not only maintained, but, rather, expanded.

This result supports and extends our previous findings that $\mathrm{CD} 34^{+} \mathrm{CB}$ cells could be grown in vitro for an extremely long period of time, during which a massive and continuously increasing production of $\mathrm{CD} 34^{+}, \mathrm{CD} 34^{+} \mathrm{CD} 38^{-}$cells, committed unipotent and multipotent progenitors occurred; also primitive stem cells, identified in vitro as LTC-IC were shown to be amplified more than 200,000-fold after 20 weeks. It was concluded that the extremely prolonged and impressive expansion of progenitors belonging to all of the hematopoietic lineages was supported by a similar expansion of primitive progenitors and that in our system, some degree of self-renewal, beside differentiation, was taking place..$^{27,28}$

The culture conditions used in the present study were similar to those previously reported and yielded similar numbers of CFC and LTC-IC, attesting that the small-scale demidepopulation assay could be reproduced in a larger scale expansion 
Table 5. Determination of the Cell Number, CFC, LTC-IC, and the Ability to Engraft the BM of NOD/SCID Recipients by Human CB Cells During Stroma-Free Cultures

\begin{tabular}{|c|c|c|c|c|c|c|c|c|c|}
\hline \multicolumn{5}{|c|}{ In Culture } & \multicolumn{3}{|c|}{ Injected/Mouse } & \multicolumn{2}{|c|}{ Engraftment } \\
\hline $\begin{array}{l}\text { Source } \\
\text { of Cells }\end{array}$ & $\begin{array}{l}\text { Growth Factors } \\
\text { Added }\end{array}$ & $\begin{array}{c}\text { Cells } \\
\text { (fold increase) }\end{array}$ & $\begin{array}{c}\text { CFC } \\
\text { (fold increase) }\end{array}$ & $\begin{array}{c}\text { LTC-IC } \\
\text { (fold increase) }\end{array}$ & Cells & CFC & LTC-IC & $\begin{array}{c}\% \text { of Human } \\
\text { Cells* }\end{array}$ & $\begin{array}{l}\text { Human } \mathrm{CFCl} \\
\text { mouse } \times 10^{3} \dagger\end{array}$ \\
\hline \multirow[t]{4}{*}{ Start } & & 10,000 & 866.4 & 1,332 & 10,000 & 866.4 & 1,332 & 0,0 & 0,0 \\
\hline & & & & & 5,000 & 433 & 666 & 0,0 & 0,0 \\
\hline & & & & & 2,500 & 216 & 333 & 0,0 & 0,0 \\
\hline & & & & & 1,250 & 108 & 166 & 0,0 & 0,0 \\
\hline \multirow[t]{2}{*}{4 weeks } & $+\mathrm{IL}-6+\mathrm{SCF}+$ & $3.16 \times 10^{6}$ & 37,184 & 11,248 & $3.160 \times 10^{6}$ & 37,184 & 11,248 & $8.5,9.9$ & $15.64,18.4$ \\
\hline & $\mathrm{FL}+\mathrm{MGDF}$ & (316) & (43) & $(8.4)$ & $0.395 \times 10^{6}$ & 4,648 & 1,456 & $2.5,3$ & $7.2,9.6$ \\
\hline \multirow[t]{3}{*}{8 weeks } & $+\mathrm{IL}-6+\mathrm{SCF}+$ & $28.99 \times 10^{6}$ & 129,464 & 56,304 & $28.99 \times 10^{6}$ & 129,464 & 56,304 & $7.3,18$ & $18.22,36.72$ \\
\hline & $\mathrm{FL}+\mathrm{MGDF}$ & $(2,899)$ & (149) & $(42)$ & $3.60 \times 10^{6}$ & 16,183 & 7,038 & $2.8,3.6$ & ND, 34.32 \\
\hline & & & & & $1.80 \times 10^{6}$ & 8,091 & 3,519 & $0.7,1.9$ & $1.34,3.87$ \\
\hline \multirow[t]{4}{*}{12 weeks } & +IL-6 + SCF + & $109 \times 10^{6}$ & $2,909,061$ & 382,284 & $109 \times 10^{6}$ & - & - & $-\quad-$ & \\
\hline & $\mathrm{FL}+\mathrm{MGDF}$ & $(10,900)$ & $(3,358)$ & $(287)$ & $13.6 \times 10^{6}$ & 363,632 & 47,785 & 11,16 & $34.98,50.76$ \\
\hline & & & & & $6.8 \times 10^{6}$ & 181,816 & 23,892 & $8,6.8$ & $23.44,44.66$ \\
\hline & & & & & $3.4 \times 10^{6}$ & 90,908 & 11,946 & $1.4,0.9$ & $12.6,19.3$ \\
\hline \multirow[t]{4}{*}{ Start } & & 20,000 & 2,248 & 3,632 & 20,000 & 3,248 & 3,632 & 0,0 & $2.08,0$ \\
\hline & & & & & 5,000 & 812 & 908 & 0,0 & 0,0 \\
\hline & & & & & 2,500 & 406 & 454 & 0,0 & 0,0 \\
\hline & & & & & 1,250 & 203 & 227 & 0,0 & 0,0 \\
\hline \multirow[t]{9}{*}{7 weeks } & $\mathrm{FL}+\mathrm{MGDF}$ & $22 \times 10^{6}$ & 372,736 & 90,112 & $22 \times 10^{6}$ & 124,930 & 90,112 & $6.8,15$ & $29.9,63.84$ \\
\hline & & $(1,100)$ & (166) & (25) & $2.75 \times 10^{6}$ & 15,616 & 11,264 & 4,11 & $8.3,75.9$ \\
\hline & & & & & $1.37 \times 10^{6}$ & 7,808 & 5,632 & $0,2.6$ & $0,13.4$ \\
\hline & $\mathrm{SCF}+\mathrm{FL}+$ & $36.4 \times 10^{6}$ & 381,728 & 126,976 & $36.40 \times 10^{6}$ & 381,728 & 126,976 & $7.8,14.2$ & $41.87,46.86$ \\
\hline & MGDF & $(1,820)$ & $(170)$ & (35) & $4.55 \times 10^{6}$ & 47,716 & 15,872 & $5.6,9$ & $2.08, N D$ \\
\hline & & & & & $2.27 \times 10^{6}$ & 23,858 & 7,936 & $0.9,3$ & $2.54,10.1$ \\
\hline & $\mathrm{IL}-6+\mathrm{SCF}+$ & $17.8 \times 10^{6}$ & 361,081 & 102,400 & $17.80 \times 10^{6}$ & 361,081 & 102,400 & $18,10.4$ & $108.9,54.16$ \\
\hline & $\mathrm{FL}+\mathrm{MGDF}$ & (890) & (160) & (28) & $2.22 \times 10^{6}$ & 45,135 & 12,800 & 4,6 & ND, 23.9 \\
\hline & & & & & $1.11 \times 10^{6}$ & 22,567 & 6,400 & $1,2.1$ & $6.32,15.6$ \\
\hline \multirow[t]{5}{*}{12 weeks } & $\mathrm{IL}-6+\mathrm{SCF}+$ & $710 \times 10^{6}$ & $2,928,640$ & 980,460 & - & - & - & $-\quad-$ & $-\quad-$ \\
\hline & $\mathrm{FL}+\mathrm{MGDF}$ & $(35,500)$ & $(1,303)$ & $(270)$ & $88.75 \times 10^{6}$ & 366,080 & 122,580 & ND, ND & ND, ND \\
\hline & & & & & $22.20 \times 10^{6}$ & 91,520 & 30,641 & $11,6.5$ & $50.16,30.07$ \\
\hline & & & & & $11.10 \times 10^{6}$ & 45,760 & 15,322 & $0.6,3.9$ & $1.87,6$ \\
\hline & & & & & $5.50 \times 10^{6}$ & 22,880 & 7,661 & $0.9,0.5$ & $5.56,2.3$ \\
\hline
\end{tabular}

The value in parentheses represents the fold increase compared with input values.

*Each value represents the percent of human $\mathrm{CD}_{4} 5^{+}, \mathrm{CD} 71^{+}$, and $\alpha-\mathrm{GPA}+$ cells in the BM of each individual mouse.

†As explained in Table 4. Expansion studies were performed in quadruplicate. Two mice were injected with each cell dose as indicated.

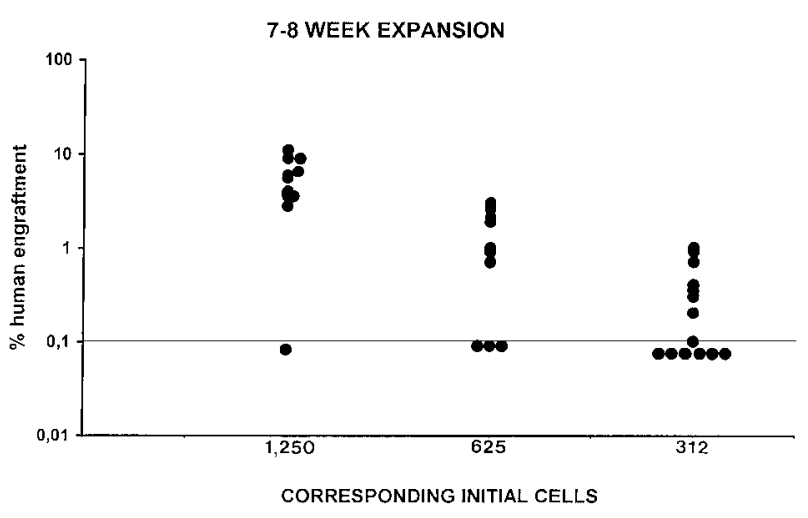

Fig 8. Summary of the level of human cell engraftment in the BM of 35 mice transplanted with cells deriving from ex vivo expansion cultures at weeks 7 to 8 in the presence of IL-6, SCF, FL, and MGDF. Individual NOD/SCID mice (each symbol represents a mouse) were injected 8 weeks previously with fractions of the expanded cells, corresponding to numbers of initial CD34 cells indicated on the abscissa. The level of human engraftment in the mouse BM was evaluated by both flow cytometry (as percent of human CD45, GpA, and CD71 positive cells) and DNA analysis as described in Materials and Methods.

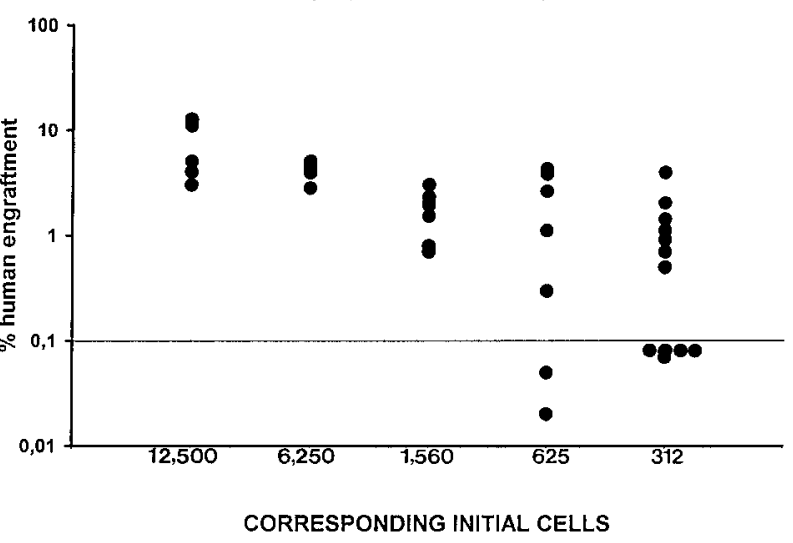

Fig 9. Summary of the level of human cell engraftment in the BM of $\mathbf{3 5}$ mice transplanted $\mathbf{8}$ weeks previously with cells deriving from ex vivo expansion cultures at weeks 9 to 10 in the presence of IL-6, SCF, FL, and MGDF. Individual NOD/SCID mice (each symbol represents a mouse) were injected with fractions of the expanded cells, corresponding to numbers of initial $\mathrm{CD}^{+} 4^{+}$cells indicated on the abscissa. The level of human engraftment in the mouse BM was evaluated by both flow cytometry and DNA analysis as described in Materials and Methods. 


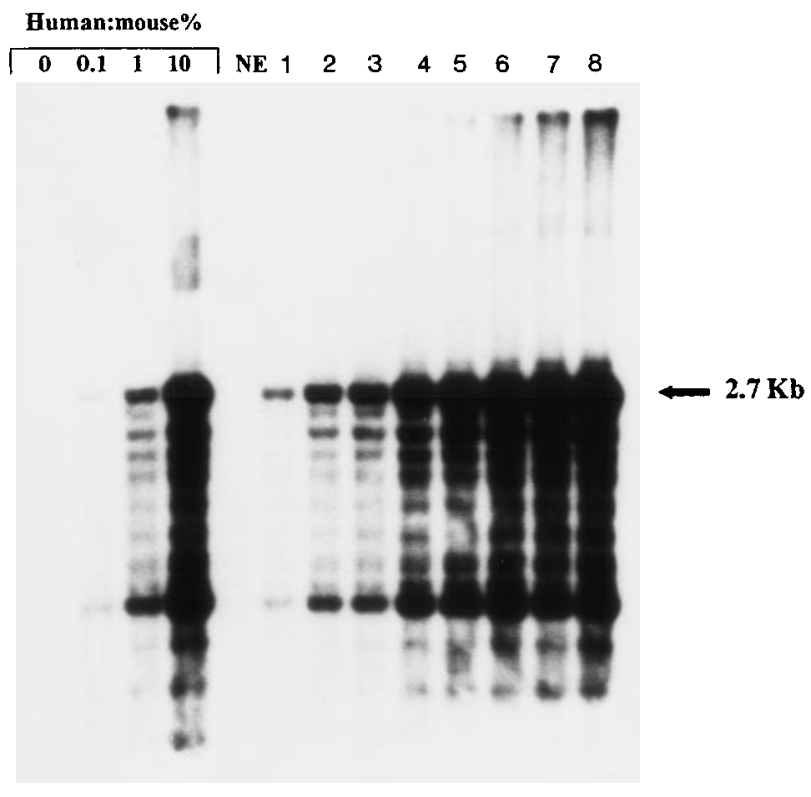

Fig 10. Representative Southem blot analysis of individual NOD/ SCID mice transplanted with expanded cells from replicate flasks at week 10 of expansion. Quadruplicate cultures were initiated with $2 \times$ $10^{4} \mathrm{CD} 34^{+}$CB cells. After 10 weeks of expansion, 2 mice were injected with the corresponding progeny of initial $\mathrm{CD} 34^{+}$cells ( 1 mouse per expansion) lanes 8 to 9; 2 mice with $1 / 12$ of the expanded cells (corresponding to initial 1,560 CD34+ cells) lanes 6 to 7; 2 mice with $1 / 32$ (=625 initial cells) lanes 4 to 5 ; and 2 mice with $1 / 64$ (=312 initial cells) lanes 2 to 3. Lane 1: A nonengrafted mouse (inoculated with $2 \times$ $10^{4} \mathrm{CD}^{4} 4^{+}$cells at start of cultures, plus $2 \times 10^{5} \mathrm{CD} 34^{-}$irradiated CB cells).

setting without losing its initial quality. In addition, in the cultures presented here, $10 \%$ human serum was substituting for $10 \%$ FCS, therefore a further step toward a clinical application has been secured.

In the first part of our study when decreasing numbers of uncultured $\mathrm{CB} \mathrm{CD}_{3} 4^{+}$cells were injected into sublethally irradiated NOD/SCID recipients, less than $35,000 \mathrm{CD} 34^{+}$cells did not engraft the totality of the recipients. Using Poisson statistics, ${ }^{33}$ the frequency of SRC in the cryopreserved CD $34^{+}$ population was calculated to be 1 in 30,900 , while in fresh CD $34^{+}$cells, it was 1 in 29,800, which appears in keeping with that reported by others. ${ }^{14,16,33}$ Four to 10 weeks of culturing $\mathrm{CD} 34^{+} \mathrm{CB}$ cells in stroma-free cultures led to an increase in the repopulating capacity of the cultured hematopoietic cells. Injection of the cultured cells deriving from $35,000,20,000$, or 10,000 initial $\mathrm{CD} 4^{+}$cells resulted in a significant increase in the level of human engraftment, similar to that observed by injecting at least 100,000 uncultured $\mathrm{CD} 34^{+}$cells.

Limiting dilution experiments performed by injecting NOD/ SCID mice with decreasing concentrations of cells expanded for up to 10 weeks allowed us to show that the frequency of SRCs after 7 to 8 weeks of expansion was 1 in 471 and after 9 to 10 weeks, it was 1 in 391 input $\mathrm{CD} 34^{+}$cells, therefore the expansion of SRC was 65-fold and 78-fold, respectively, 60-fold and 70-fold if compared with the frequency of SRC in fresh $\mathrm{CD}_{3}{ }^{+} \mathrm{CB}$ cells. Recently, it has been reported that incubation of $\mathrm{CD} 34^{+} \mathrm{CD} 38^{-} \mathrm{CB}$ cells in serum-free medium containing FL, SCF, IL-3, IL-6, and G-CSF for 5 to 8 days, resulted in a 100-fold expansion of CFC, a 4-fold expansion of
LTC-IC, and a modest (2-fold), but significant, increase of CRU. CRU were found, although at different frequencies, also in the $\mathrm{CD} 34^{+} \mathrm{CD} 38^{+} \mathrm{CB}$ subpopulations and with a distribution between the two CB subsets as LTC-IC. It was concluded that conditions, which were able to stimulate LTC-IC expansion, might also stimulate increases in CRU. ${ }^{16}$ Similarly, Bhatia et $\mathrm{al}^{29}$ showed a fourfold increase of SRC after a 4-day incubation of $\mathrm{CD} 34^{+} \mathrm{CD} 38^{-} \mathrm{CB}$ cells in stroma-free conditions; SRC, however, were lost after 9 days of culture. Gan et $\mathrm{al}^{30}$ reported that cocultures of $\mathrm{BM}$ or $\mathrm{CB}$ cells on allogeneic stroma layers for up to 3 weeks resulted in a decrease and a final loss of in vivo repopulating ability in NOD/SCID mice recipients; in contrast to the loss of SRC, the cultured cells frequently contained an equal or higher number of LTC-IC compared with the fresh cells. Additionally, while this report was being revised, it was reported that human $\mathrm{CD} 34^{+} \mathrm{CD} 38^{-} \mathrm{BM}$ cells, after 6-day stroma-free suspension cultures containing FL, TPO, and SCF retained their in vivo repopulating capacity in the SCID/hu bone assay. ${ }^{34}$ Also, $\mathrm{Xu}$ et $\mathrm{al}^{31}$ recently showed that $\mathrm{CB}$ cells could maintain their in vivo repopulating ability after at least 4 weeks of coculture on a stromal cell line derived from the aorta-gonadmesonephros region of mouse embryo.

Cell populations, culture conditions (stromal cocultures or stroma-free cultures), as well as the growth factors used in the various studies are different, therefore the somewhat different results cannot be compared. However, it is becoming increasingly evident that primitive stem cells, defined by their ability to completely engraft a myeloablated recipient, can be maintained in vitro for long periods of time and are likely to undergo self-renewal divisions.

A very controversial issue is the role played by stroma cocultures: even though the presence of BM stroma layers has been shown to increase the frequency of gene transfer into primitive cells, compared with using viral supernatants and to prevent the loss of stem cell quality during ex vivo expansion of peripheral blood stem cells, ${ }^{35-37}$ other reports suggest that the long-term repopulating ability of cultured cells decreases using BM stroma cocultures. ${ }^{38,39}$

The vast majority of prior studies aimed at developing clinical applications of expansion protocols have adopted culture conditions that resulted in a marked expansion of cell counts, CD $34^{+}$cells, CFC, and even LTC-IC in a short period of time. However, the expansion was transient, soon followed by a rapid decline of cell number, of CFC output, and disappearance of LTC-IC, which indicated the exhaustion of the stem cell pool. In our culture system, it is possible to obtain very large numbers of cells and progenitors belonging to the more mature hematopoietic compartments and, at the same time, to maintain and even expand several-fold the primitive in vivo repopulating stem cells. This information could prove essential to design and test conditions for ex vivo activation and expansion of immature hematopoietic cells and for various experimental purposes, such as required for the development of efficient gene transfer protocols into hematopoietic cells with retention of repopulating ability.

\section{REFERENCES}

1. Spangrude G, Smith L, Uchida N, Ikuta F, Heimfeld S, Friedman J, Weissman IL: Mouse hematopoietic stem cells. Blood 78:1395, 1991 
2. Ogawa M: Differentiation and proliferation of hematopoietic stem cells. Blood 81:2844, 1993

3. Berardi AC, Wang A, Levine JD, Lopez P, Scadden DT: Functional isolation and characterization of human hematopoietic stem cells. Science 267:104, 1995

4. To LB, Haylock DN, Simmons PJ, Juttner CA: The biology and clinical uses of blood stem cells. Blood 89:2233, 1997

5. Sutherland HJ, Lansdorp PM, Henkelman DH, Eaves AC, Eaves CJ: Functional characterization of individual human hematopoietic cells cultured at limiting dilution on supportive marrow stromal layers. Proc Natl Acad Sci USA 87:3584, 1990

6. Hao QL, Shah AJ, Thienmann FT, Smogorzewska EM, Crooks GM: A functional comparison of $\mathrm{CD} 34^{+} \mathrm{CD} 38^{-}$cells in cord blood and bone marrow. Blood 86:3745, 1995

7. Kamel-Reid S, Dick JE: Engraftment of immune-deficient mice with human hematopoietic stem cells. Science 242:1706, 1988

8. Lapidot T, Pflumio F, Doedens M, Murdoch B, Williams DE, Dick JE: Cytokine stimulation of multilineage hematopoiesis from immature human cells engrafted into SCID mice. Science 255:1137, 1992

9. Kyoizumi S, Baum CM, Kaneshima H, McCune JM, Yee EJ, Namikawa R: Implantation and maintenance of functional human bone marrow in SCID-hu mice. Blood 79:1704, 1992

10. Nolta JA, Hanley MB, Kohn DB: Sustained human hematopoiesis in immunodeficient mice by cotransplantation of marrow stroma expressing human interleukin-3: Analysis of gene transduction of long-lived progenitors. Blood 83:3041, 1994

11. Lowry PA, Shultz LD, Greiner DL, Hesselton RM, Kittler ELW, Tiarks CY, Rao SS, Reilly J, Leif JH, Ramshaw H, Stewart FM, Quesenberry PJ: Improved engraftment of human cord blood cells in NOD/LtSz-scid/scid mice after irradiation or multiple-day injections into unirradiated recipients. Biol Blood Marrow Transplant 2:15, 1996

12. Pflumio F, Izac B, Katz A, Shultz LD, Vainchenker W, Coulombel L: Phenotype and function of human hematopoietic cells engrafting immune-deficient CB17-severe combined immunodeficiency mice and nonobese diabetic-severe combined immunodeficiency mice after transplantation of human cord blood mononuclear cells. Blood 88:3731, 1996

13. Cashman JD, Lapidot T, Wang JCY, Doedens M, Shultz LD, Lansdorp P, Dick JE, Eaves CJ: Kinetic evidence of the regeneration of multi-lineage hematopoiesis from primitive cells in normal human bone marrow transplanted into immunodeficient mice. Blood 89:4307, 1997

14. Hogan CJ, Shpall EJ, McNulty O, McNiece I, Dick JE, Shultz LD, Keller G: Engraftment and development of human CD34+enriched cells from umbilical cord blood in NOD/LtSz-scid/scid Mice. Blood 90:85, 1997

15. Dick JE: Normal and leukemic human stem cells assayed in SCID mice. Semin Immunol 8:197, 1996

16. Conneally E, Cashman J, Petzer A, Eaves C: Expansion in vitro of transplantable human cord blood stem cells demonstrated using a quantitative assay of their lympho-myeloid repopulating activity in nonobese diabetic-scid/scid mice. Proc Natl Acad Sci USA:94:9836, 1997

17. Larochelle A, Vormoor J, Hanenberg H, Wang JCY, Bhatia M, Lapidot T, Moritz T, Murdoch B, Xiao XL, Kato I, Williams DA, Dick JE: Identification of primitive human hematopoietic cells capable of repopulating NOD/SCID mouse bone marrow: Implications for gene therapy. Nat Med 2:1329, 1996

18. Bhatia M, Wang JCY, Kapp U, Bonnet D, Dick JE: Purification of primitive human hematopoietic cells capable of repopulating immunedeficient mice. Proc Natl Acad Sci USA 94:5320, 1997

19. Cashman J, Bockhold K, Hogge DE, Eaves AC, Eaves CJ: Sustained proliferation, multi-lineage differentiation and maintenance of primitive human hemopoietic cells in NOD/SCID mice transplanted with human cord blood. Br J Haematol 97:1026, 1997
20. Gluckman E, Broxmeyer HE, Auerbach AD, Friedman H, Douglas G, Devergie A, Esperou H, Thierry D, Socie G, Lehn P, Cooper S, English D, Kurtzberg J, Bard J, Boyse E: Hematopoietic reconstitution in a patient with Fanconi's anemia by means of umbilical cord blood from an HLA-identical sibling. N Engl J Med 321:1174, 1989

21. Broxmeyer HE, Gluckman E, Auerbach AD, Douglas GW, Friedman H, Cooper S, Hangoc G, Kurtzberg J, Bard J, Boyse EA: Human umbilical cord blood: A clinically useful source of transplantable hematopoietic stem/progenitor cells. Int J Cell Cloning 8:76, 1990

22. Hows JM, Bradley BA, Marsh JCW, Luft T, Coutinho L, Testa NG, Dexter TM: Growth of umbilical cord blood in longterm haemopoietic cultures. Lancet 340:73, 1992

23. Lu L, Xiao M, Shen R-N, Grigsby S, Broxmeyer HE: Enrichment, characterization and responsiveness of single primitive $\mathrm{CD} 34+++$ human umbilical cord blood hematopoietic progenitors with high proliferative and replating potential. Blood 81:41, 1993

24. Cairo MS, Wagner JE: Placental and/or umbilical cord blood: An alternative source of hematopoietic stem cells for transplantation. Blood 90:4665, 1997

25. Petzer AL, Hogge DE, Lansdorp PM, Reid DS, Eaves CJ: Self-renewal of primitive human hematopoietic cells (long-term-cultureinitiating cells) in vitro and their expansion in defined medium. Proc Natl Acad Sci USA 93:1470, 1996

26. Petzer AL, Zandstra PW, Piret JM, Eaves CJ: Differential cytokine effects on primitive $(\mathrm{CD} 34+\mathrm{CD} 38$-) human hematopoietic cells: Novel responses to Flt3-ligand and thrombopoietin. J Exp Med 183:2551, 1996

27. Piacibello W, Sanavio F, Garetto L, Severino A, Bergandi D, Ferrario J, Fagioli F, Berger M, Aglietta M: Extensive amplification and self-renewal of human primitive hematopoietic stem cells from cord blood. Blood 89:2644, 1997

28. Piacibello W, Sanavio F, Garetto L, Severino A, Danè A, Gammaitoni L, Aglietta M: Differential growth factor requirement of primitive cord blood hematopoietic stem cell for self-renewal and amplification vs proliferation and differentiation. Leukemia 12:718, 1998

29. Bhatia M, Bonnet D, Kapp U, Wang CY, Murdoch B, Dick JE: Quantitative analysis reveals expansion of human hematopoietic repopulating cells after short-term ex vivo culture. J Exp Med 186:619, 1997

30. Gan OI, Murdoch B, Larochelle A, Dick JE: Differential maintenance of primitive human SCID-repopulating cells, clonogenic progenitors, and long-term culture-initiating cells after incubation on human bone marrow stromal cells. Blood 90:641, 1997

31. Xu M, Tsuji K, Ueda T, Mukouyama Y, Hara T, Yang F, Ebihara Y, Matsuoka S, Manabe A, Kikuchi A, Ito M, Miyajima A, Nakahata T: Stimulation of mouse and human primitive hematopoiesis by murine embryonic aorta-gonad-mesonephros-derived stromal cell lines. Blood 92:3032, 1998

32. Taswell C: Limiting dilution assays for the determination of immunocompetent cell frequencies: I. Data analysis. J Immunol 26: 1614,1981

33. Wang JCY, Doedens M, Dick JE: Primitive human hematopoietic cells are enriched in cord blood compared to adult bone marrow or mobilized peripheral blood as measured by the quantitative in vivo SCID-repopulating cell (SRC) assay. Blood 89:3924, 1997

34. Luens KM, Travis MA, Chen BP, Hill BL, Scollay R, Murray LJ: Thrombopoietin, kit ligand, flk $2 / \mathrm{flt} 3$ ligand together induce increased numbers of primitive hematopoietic progenitors from human CD34+ Thy-1+ Lin- cells with preserved ability to engraft SCID-hu bone. Blood 91:1206, 1998

35. Moore KA, Deisseroth AB, Reading CL, Williams DE, Belmont 
JW: Stromal support enhances cell-free retroviral vector transduction of human bone marrow long-term culture-initiating cells. Blood 79:1393, 1992

36. Nolta JA, Smogorzewska EM, Kohn DB: Analysis of optimal conditions for retroviral-mediated transduction of primitive human hematopoietic cells. Blood 86:101, 1995

37. Breems DA, Blokland EAW, Siebel KE, Mayen AEM, Engels LJA, Ploemacher RE: Stroma-contact prevents loss of hematopoietic- stem cell quality during ex vivo expansion of CD34+ mobilized peripheral blood stem cells. Blood 91:111, 1998

38. Harrison DE, Lerner CP, Spooncer E: Erythropoietic repopulating ability of stem cells from long-term marrow culture. Blood 69:1021, 1997

39. Van der Sluijs JP, van den Bos C, Baert MRM, van Beurden CAJ, Ploemacher RE: Loss of long-term repopulating ability in long-term bone marrow culture. Leukemia 7:725, 1993 